\title{
Perikopa o kamenu ugaonom i narodu Božjem - kraljevskom svećenstvu u Prvoj Petrovoj poslanici (1 Pt 2, 4-10)
}

\author{
Mario CIFRAK - Vedran PAVLIĆ* \\ UDK: 27-248.78 • Pregledni članak \\ Primljeno: 26. rujna 2016. P Prihvaćeno: 27. veljače 2017.
}

${ }^{*}$ Izv. prof. dr. sc. Mario

Cifrak, Katolički

bogoslovni fakultet

Sveučilišta u Zagrebu,

Vlaška 38, 10000

Zagreb, Hrvatska, mario.cifrak@ofm.hr

Vedran Pavlić, mag. theol.,

Karmel - Remete, Ivana

Česmičkoga 1, 10000

Zagreb, Hrvatska, vedranpavlic.ocd@ gmail.com

Sažetak: Prva Petrova poslanica u perikopi 1 Pt 2, 4-10, govoreći o Kristu, kamenu ugaonom, te o narodu Božjem, ovdje nazvanom kraljevskim svećenstvom, očituje specifičnu petrovsku ekleziološku sliku. Do ekleziološki relevantnih rezultata u ovom se radu došlo egzegetskom analizom koristeći se pritom tehnikom hermeneutike Staroga zavjeta u Novom zavjetu, egzegetskom analizom s kontekstualizacijom važnijih motiva prisutnih u perikopi i daljnjom egzegetskom i biblijsko-teološkom analizom oslonjenom na literaturu bibličara egzegeta koji su komentirali tu perikopu. Značajni motivi koji se nalaze u perikopi posjeduju ne samo novozavjetni kontekst s kristološkim ili ekleziološkim značenjem i implikacijama već imaju i svoju starozavjetnu pozadinu, kontekst i semantiku. Motiv kraljevskoga svećenstva koji u toj perikopi ukazuje na cijeli narod Božji, na kršćane vjernike, dakle na cijelu Ekklesiu, u događajima reformacije 16. stoljeća pogrješno se tumači (osobito redak 1 Pt 2, 9 perikope) dovodeći do teoloških iskrivljavanja na dogmatskom području. Perikopu Drugi vatikanski koncil citira u svojim dokumentima (SC 14, AA 3, PO 2, AG 15 i osobito u LG 6; 9; 10; 34) tumačeći ekleziologiju izrazima iz perikope, od kojih su osobito značajne slike Crkve kao naroda Božjega i kraljevskoga svećenstva, tj. općega svećenstva krštenih vjernika.

Ključne riječi: Prva Petrova poslanica, kamen ugaoni, narod Božji, kraljevsko svećenstvo, hermeneutika Staroga zavjeta u Novom zavjetu, ministerijalno i opće ili krsno svećenstvo. 


\section{Uvod}

Prva Petrova poslanica ubraja se u sedam katoličkih (općih) poslanica (Jakovljeva, dvije Petrove, tri Ivanove i Judina). Premda tradicija pripisuje te poslanice apostolima Petru, Ivanu i dvojici iz Isusove obitelji, Jakovu i Judi, bibličari se danas uvelike opredjeljuju za pseudonimno autorstvo tih poslanica, na što ih navode suvremena egzegetska istraživanja koja nastanak Prve Petrove poslanice smještaju u devedesete godine prvoga stoljeća. Još uvijek postoji velik broj bibličara koji upravo za Prvu Petrovu poslanicu smatra da je doista moguće da ju je napisao Petar uz pomoć tajnika Silvana, dakle ne vlastoručno (oko 60. - 64. g.), no znatan je i broj onih koji tvrde da je vjerojatnije autorstvo nekoga učenika koji se oslanjao na Petrovu baštinu u Rimu ${ }^{1}$ (oko 70. - 90. g. ili čak do 117. g. npr. u doba cara Domicijana ili Trajana). ${ }^{2}$ Jedinstvo poslanice zastupa većina stručnjaka, a primjećuje se i prisutnost vjeroispovjednoga himna ili ulomka, odnosno katehetskoga obrasca umetnutoga u poslanicu. Poslanica prema formi ${ }^{3}$ posjeduje uvodnu ( $\left.1 \mathrm{Pt} 1,1-2\right)$ i zaključnu formulu ( 1 Pt 5, 12-14), a središnji dio govori o potvrdi kršćanskoga identiteta i dostojanstva (1 $\mathrm{Pt} 1,3-2,10)$, o prikladnom ponašanju radi svjedočenja poganskom svijetu (1 $\mathrm{Pt} 2,11-3,12)$ i o kršćanskom ponašanju u neprijateljskom okruženju (1 Pt 3, 13$5,11)$. Perikopa o kamenu ugaonom i narodu Božjem, kraljevskom svećenstvu, (1 Pt 2, 4-10) pripada prvoj podcjelini središnjega dijela i predstavlja svojevrsni zaključak te podcjeline, a osim toga sadrži doktrinarni, teološki sadržaj. Perikopa će se egzegetski analizirati kroz etape: delimitacija teksta, starozavjetni citati, prikaz strukture teksta i analiza motiva. Ovaj rad donosi i pregled nekih egzegetskih razmatranja o različitim elementima te teološki bogate i složene perikope.

\section{Delimitacija teksta}

Za egzegetsku delimitaciju teksta važno je uočiti promjene četiriju važnih odrednica u tekstu, a to su mjesto, vrijeme, osobe (akteri u radnji) ${ }^{4} \mathrm{i}$ tema radnje te ako se jedna ili čak više tih odrednica promijeni, time je delimitirana nova, tj. sljedeća perikopa teksta. Perikopi 1 Pt 2, 4-10 prethodi perikopa 1 Pt 1, 22-2, 3 koja navo-

\footnotetext{
${ }^{1}$ Usp. R. E. BROWN, Uvod u Novi zavjet, Zagreb, 2008., 711.-712.

${ }^{2}$ Usp. W. J. HARRINGTON, Uvod u Novi zavjet - spomen ispunjenja, Zagreb, 1993., 381.

${ }^{3}$ Usp. R. E. BROWN, Uvod u Novi zavjet, 712.

${ }^{4}$ Autor poslanice obraća se na početku poslanice putnicima raseljeništva u Pontu, Galaciji, Kapadociji, Aziji i Bitiniji (1 Pt 1, 1), no u poslanici se autor obraća pojedinim skupinama kršćana na različite načine (npr. poticaji, blagoslovi, savjeti, imperativi, zaklinjanja, davanje primjera itd.), a te su skupine kršćana različite. Najčešće se autor poslanice obraća općenito kršćanima, ali se na određenim mjestima obraća slugama, ženama i muževima u braku, onima koji trpe, tj. podnose patnje, starješinama i mladićima. S pomoću takvih promjena u samom tekstu poslanice moguće je delimitirati pojedine perikope.
} 
di nekoliko savjeta koji se tiču zajedničkoga života: nehinjeno bratoljublje, žarka ljubav, odlaganje svake zloće, prijevare, himbe, zavisti i klevetanja te žudnja za duhovnom hranom. Sljedeća je perikopa 1 Pt 2, 11-12 koja pruža opću izjavu o tome kako se treba ponašati među poganima, tj. kloneći se putenih požuda koje se bore protiv duše, posjedovati uzornost življenja među poganima i činiti dobra djela ne bi li i pogani time potaknuti proslavili Boga. Perikopa $1 \mathrm{Pt} \mathrm{2,} \mathrm{4-10} \mathrm{govori} \mathrm{o} \mathrm{tome}$ kako je Bog izabrao kršćane da se ugrade u duhovni dom, zato da bi naviještali silna djela onoga koji ih je pozvao u svjetlost, tj. navode se ukratko povlastice pripadnika Božjega naroda.

\section{Citati Staroga zavjeta u perikopi}

Hermeneutika Staroga zavjeta u Novom zavjetu posebna je znanstvena metoda koja proučava ulogu i poruku starozavjetnih citata u knjigama Novoga zavjeta, a tom metodom egzegetima je moguće iznijeti preciznije zaključke o samoj teologiji u pojedinoj novozavjetnoj perikopi ili u pojedinoj novozavjetnoj knjizi. Neupitna je važnost i pomoć koju ta suvremena disciplina pruža znanstvenim biblijskim proučavanjima, no metodološki pristup ovdje zahtijeva poredbene analize originalnih starozavjetnih tekstova, kao i dodatne analize starozavjetnih motiva citiranih u novozavjetnoj perikopi. Dolje su navedeni paralelni dijelovi starozavjetnih citata iz Septuaginte (LXX) i iz perikope (1 Pt 2, 4-10) s prijevodima, a starozavjetni paralelni dio teksta ili komentar s prijevodom pojedinih paralelnih izraza iz tzv. textus masoreticus (textus receptus) na hebrejskom jeziku nalaze se u podnožnoj napomeni. Prijevod je iz zagrebačke Biblije ${ }^{5}$ i, naravno, ne predstavlja doslovni prijevod iz Septuaginte.

\subsection{Iz 28, 16 PARALELA S 1 PT 2, 6}

Citat iz Iz 28, 16 predstavlja proroštvo (mesijansko proroštvo prema katoličkim egzegetima) i nalazi se u većoj cjelini, u kojoj se u obliku pjesama govori o Samariji i Judeji, govorom u opomenama, prijetnjama protiv svećenika, lažnih proroka i zlih savjetnika. To proroštvo (Iz 28, 16-17) uokvireno je govorom protiv vladajućih u Jeruzalemu koji posežu za lažima. Motiv Siona, jeruzalemske gore, jasno je ovdje uklopljen, a motiv kamena koji se ovdje pojavljuje upotrijebljen je kako bi simbolički označavao stabilnost usred nestabilnosti koju prouzrokuju laži. ${ }^{6} \mathrm{Sep}-$ tuagintin tekst toga retka $(\mathrm{Iz} 28,16)$ ima sljedeće paralelne izraze: $\operatorname{Iz} 28,16:^{7} \gg \ldots$

\footnotetext{
${ }^{5}$ Sveto pismo Staroga i Novoga zavjeta, Zagreb, 2008.

${ }^{6}$ Osobito kod vladajućih u Jeruzalemu.

${ }^{7}$ Hebrejski tekst: Iz 28, 16

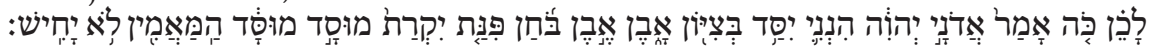




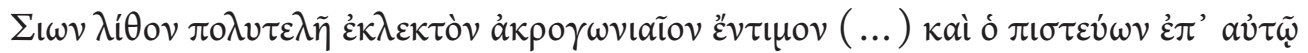

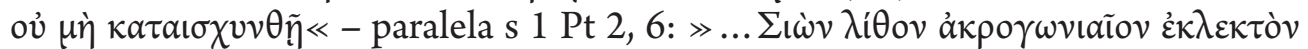

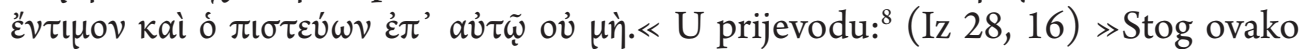
govori Jahve Gospod: 'Evo, postavljam na Sion kamen odabrani, dragocjen kamen ugaoni, temeljac. Onaj koji u nj vjeruje, neće propasti.'«; (1 Pt 2, 6) »Stoga stoji u Pismu: Evo postavljam na Sionu kamen odabrani, dragocjeni kamen ugaoni: Tko u nj vjeruje, ne, neće biti postiđen.«

\subsection{Ps 118, 22 (117, 22; LXX) PARALELA S 1 Pт 2,7}

Psalam 118 korišten je u obredima za blagdan Sjenica, a usto predstavlja i pjesmu zahvalnicu za pobjedu nad Antiohovom vojskom i popratna je pjesma hramskoga očišćenja i ponovnoga otvaranja obredima. U novozavjetnim spisima poprimio je kristološko značenje u retku Ps 118, 22 jer taj redak kod sinoptika primijenjen je na Isusa u Isusovoj prispodobi o vinogradarima ubojicama. U Psalmu psalmist koji je u nevolji prikazuje se kao kamen čija je stabilnost u pravednosti ( $\gg$ vrata pravde $\ll$, »na njih ulaze pravedni $\ll$, »šatori pravednika «), a nevolje, dušmani i pogani koji okružuju psalmista predstavljaju graditelje koji ga odbacuju. U kristološkom tumačenju kamen je Krist, kako je kod sinoptika prikazano u Isusovoj prispodobi o vinogradarima ubojicama, a autor poslanice preuzima to tumačenje (1 $\mathrm{Pt} 2,7)$. Ovdje se nameće objašnjenje za odbacivanje kamena zaglavnoga u Kristovoj osudi i odbacivanju, u Kristovoj muci, križu i smrti. To što »kamen koji odbaciše graditelji postade kamen zaglavni « tumači se kroz prizmu uskrsnuća. Kristovim uskrsnućem navješćuje se vjera u Krista koji je uskrsnuo od mrtvih i time pobijedio smrt. Krist više nije samo neki od mnoštva odbačenih kamena, već je on kamen zaglavni i temeljni za uskrsnuće svih onih koji u njega vjeruju. Septuagintin tekst toga retka

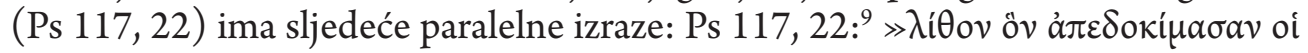

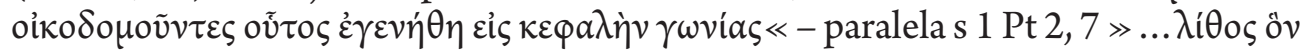

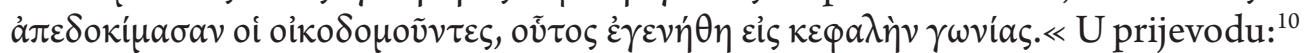
(Ps 118, 22/117, 22) »Kamen što ga odbaciše graditelji postade kamen zaglavni «; $(1 \mathrm{Pt} 2,7) \gg$ Vama dakle koji vjerujete - čast! A onima koji ne vjeruju - kamen koji odbaciše graditelji postade kamen zaglavni.«

\footnotetext{
${ }^{8}$ Prijevod bi hebrejskoga teksta glasio: »Stoga ovdje kaže Gospod Bog: ‘Gle utemeljujem na Sionu kamen, ugaoni kamen ispitivanja, dragocjeni temelj koji je utemeljen. Onaj koji u nj vjeruje neće se uznemiriti. «

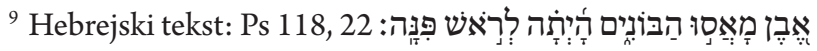

${ }^{10}$ Prijevod bi hebrejskoga teksta glasio: $\gg$ Kamen koji odbaciše oni koji grade (graditelji) postade glava ugla (zaglavni kamen).«
} 


\subsection{Iz 8, 14 Paralela s 1 PT 2,8}

Kontekst starozavjetnoga citata Iz 8, 14 jest prijetnja asirskoga kraljevstva sa sjevera, za koje prorok Izaija proriče po riječima Gospodnjim da će nagrnuti na Damask, Samariju, provaliti u Judeju i preko cijele zemlje izraelske. Gospodin poručuje po proroku neka jedino Jahve nad vojskama bude svet narodu, neka se jedino njega boje prožeti strahom jer će Jahve nad vojskama biti »zamka i kamen spoticanja i stijena posrtanja.« U Prvoj Petrovoj poslanici prisutno je kristološko tumačenje u kojemu Isus Krist predstavlja kamen spoticanja i stijenu posrtanja. Septuagintin tekst toga retka $(\mathrm{Iz} 8,14)$ ima sljedeće ključne paralelne izraze: Iz 8, 14: ${ }^{11}$

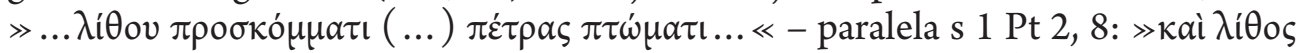

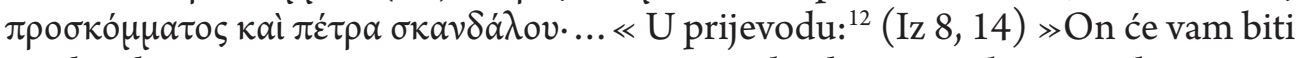
zamka i kamen spoticanja i stijena posrtanja za obje kuće Izraelove, zamka i mreža svim Jeruzalemcima.«; (1 Pt 2, 8) »i kamen spoticanja, stijena posrtanja; oni se o nj spotiču, neposlušni Riječi, za što su i određeni.«

\subsection{Iz 43, 20-21 paralela s 1 PT 2, 9}

Deuteroizaija (Iz 40-55) je prorok iz vremena babilonskoga progonstva koji je djelovao među prognanicima tješeći izabrani narod da je Bog jedini sposoban narodu dati puninu spasenja jer je moćan i kao stvoritelj svijeta, gospodar vremena i povijesti. Deuteroizaija proriče uz tješenje sretniju budućnost naroda i povratak u domovinu kao novi Izlazak. Taj citat (Iz 43, 20-21) očituje Božju milosrdnu ljubav prema izraelskom narodu u babilonskom progonstvu. U poslanici su kršćani novi izabrani narod kojem Bog očituje svoju ljubav. Tamu nevjere zamjenjuje divno svjetlo, a uzrok tomu je vjera i pripadnost Kristu. Septuagintin tekst tih redaka

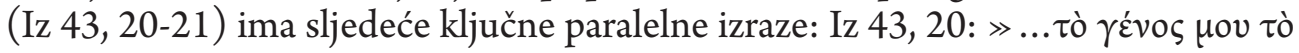

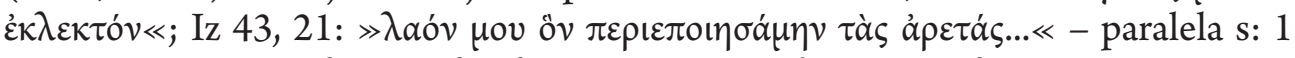

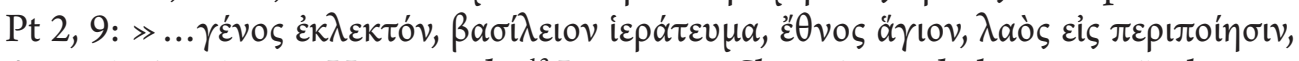

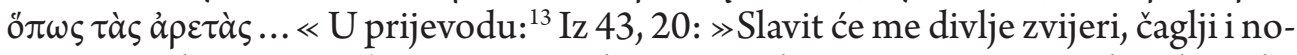
jevi, jer vodu ću stvorit' u pustinji, rijeke u stepi, da napojim svoj narod, izabranika svoga «; Iz 43, 21: »I narod koji sam sebi sazdao moju će kazivati hvalu!«; 1 Pt 2, 9: $\gg$ A vi ste rod izabrani, kraljevsko svećenstvo, sveti puk, narod stečeni da naviještate silna djela Onoga koji vas iz tame pozva k divnom svjetlu svojemu.«

\footnotetext{
${ }^{11}$ Hebrejski tekst: Iz 8, 14

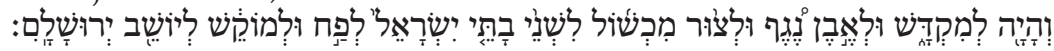

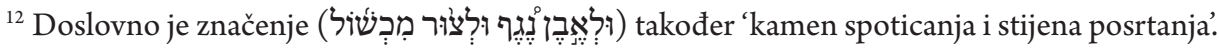

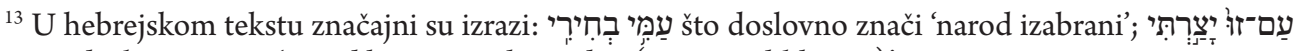
što doslovno znači 'narod koji sam sebi sazdao (stvorio, oblikovao)'.
} 


\subsection{IzL 19, 5-6 PARAlela s 1 Pt 2, 9}

Citat iz Izl 19, 5-6 smješten je u kontekstu dolaska izraelskoga naroda do Sinaja i uoči pripreme za Savez i primanja deset Božjih zapovijedi. U sklopu obećanja Boga koji je saveznik narodu nalaze se izrazi iz ovoga citata: »vi ćete mi biti kraljevstvo svećenikâ, narod svet «, koji se odnosi na Izraelce. U kristološkom čitanju u Prvoj Petrovoj poslanici isti izrazi odnose se na kršćane. Septuagintin tekst tih redaka (Izl 19, 5-6) ima sljedeće ključne paralelne izraze: Izl 19, $5 \gg \ldots$... $\mu$ เ $\lambda$ aòs... «; Izl 19, 6

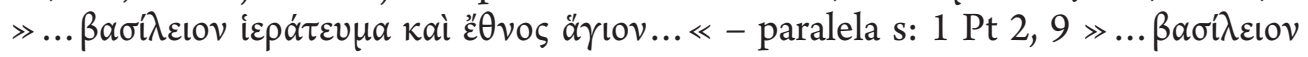

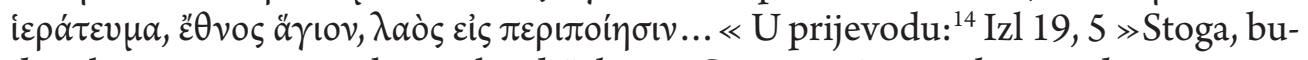
dete li mi se vjerno pokoravali i držali moj Savez, vi ćete mi biti predraga svojina mimo sve narode - ta moj je sav svijet! «; Izl 19, 6 »vi ćete mi biti kraljevstvo svećenikâ, narod svet.' Tim riječima oslovi Izraelce.«; 1 Pt 2, 9 »A vi ste rod izabrani, kraljevsko svećenstvo, sveti puk, narod stečeni da naviještate silna djela Onoga koji vas iz tame pozva $\mathrm{k}$ divnom svjetlu svojemu.«

\subsection{Izl 23, 22 (LXX) PARAlela s 1 PT 2, 9}

Septuagintin tekst pokazuje paralelu u izrazima s tekstom perikope $1 \mathrm{Pt} 2$, 4-10,

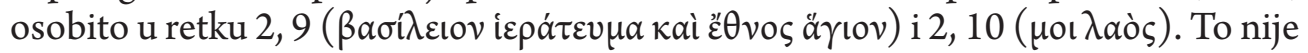
slučaj s textus masoreticus, tj. hebrejskim tekstom Izl 23, 22. Parafrazirani prijevod ${ }^{15}$ toga podužega retka u Septuaginti (Izl 23, 22, LXX) bio bi: »Ako ste čuli vijest moga glasa i učinili sve što god zapovjedih tebi i ako ste očuvali Savez moj, bit ćete moj narod izabrani, od svih naroda (baš) moj, jer je (i) sva zemlja; (ali) vi ćete biti moje kraljevsko svećenstvo i narod svet; ove riječi ćete govoriti sinovima Izraelovim; ako si vijest glasa mojega čuo i učiniš li sve štogod tebi rekoh, bit ću neprijatelj (neprijateljevat ću s) tvojim neprijateljima i suprotstavit ću se tvojim protivnicima.« Tim riječima odražavaju se Božja obećanja za poslušnost i držanje Saveza (o kojem knjiga Izlaska detaljno govori), Božja zaštita i nagrada, a to je u analogiji s odnosom vjernih kršćana i Boga u 1 Pt 2, 4-10. Septuagintin tekst toga retka (Izl 23,

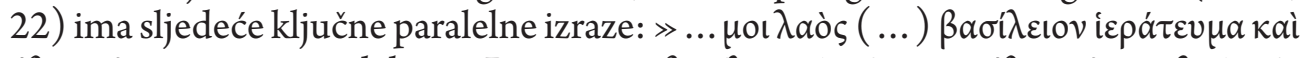

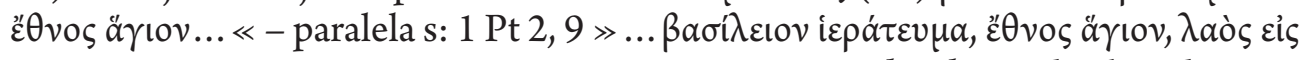

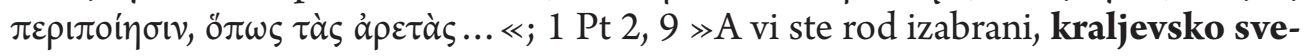
ćenstvo, sveti puk, narod stečeni da naviještate silna djela Onoga koji vas iz tame pozva $\mathrm{k}$ divnom svjetlu svojemu.«

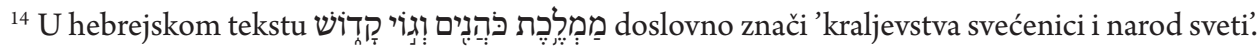

${ }^{15}$ Prijevod hebrejskoga teksta preuzet u zagrebačkoj Bibliji glasi: Izl 23, 22 »Ako mu se budeš vjerno pokoravao i budeš vršio sve što sam naredio, ja ću biti neprijatelj tvojim neprijateljima i protivnik tvojim protivnicima.«
} 


\subsection{Hoš 1 , 6-9; 2, 3; 2, 25 Paralela s 1 Pт 2,10}

Prorok Hošea djelovao je između 750. i 725. g. pr. Kr., vjerojatno prije pada Samarije. Osobitost je njegove knjige snažan emocionalni naboj koji ga tjera od razočaranja do velike ljubavi. Hošein brak s bludnicom Gomer, s kojom je dobio troje djece, kojima je nadjenuo simbolična imena prema naredbi Gospodnjoj, danas se ne smatra nužno samo alegorijom, već prevladava mišljenje o stvarnom braku koji ne isključuje metaforično značenje. ${ }^{16}$ Korelacije koje su ovdje važne jesu sljedeće: bludništvo simbolizira otpad izraelskoga naroda od Boga, te zbog toga Hošea naziva svoju djecu prema Božjem naputku - prvoga sina Jizreel (prema, doduše, plodnoj ravnici, ali povijesno preopterećenoj pokoljima), drugo dijete, kćer, Ne-Mila ili Bez-Smilovanja (לא רחמָה) (jer se Gospodin neće nastaviti smilovati kući Izra-

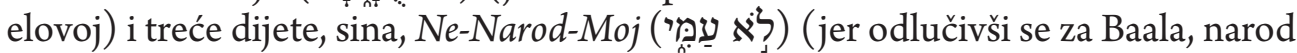
više nije Gospodinov narod). U Prvoj Petrovoj poslanici autor poslanice izrazom: »vi, nekoć Ne-narod, a sada Narod Božji; vi Ne-mili, a sada Mili «, obraća se, nesumnjivo, kršćanima koji tu promjenu postižu zahvaljujući svojoj vjeri i pripadnosti Kristu. Dok neki egzegete to tumače kao obraćanje autora kršćanima iz poganstva, ${ }^{17}$ drugi to tumače kao obraćanje autora poslanice judeokršćanima iz židovstva jer oni razumiju Pismo, pa tako i tumačenje Hošeine knjige. Pozitivni naslovi (Narod Božji i Mili) pripadaju sada ( $v \tilde{v} v)$ kršćanima, što je prikladno za svevremeno iščitavanje.

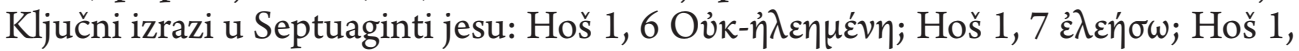

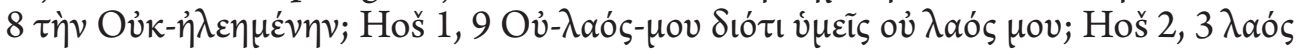

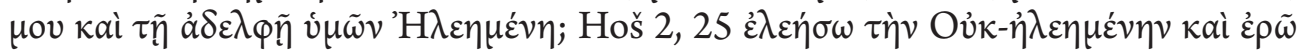

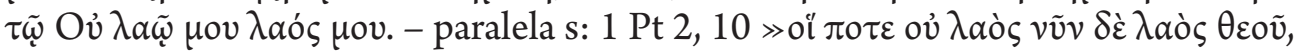

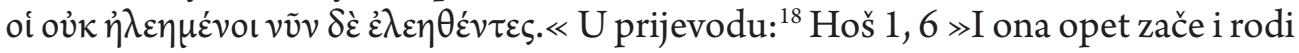
kćer. I reče mu Jahve: 'Nadjeni joj ime Nemila, jer mi odsad neće biti mila kuća Izraelova, od nje ću se povući«; Hoš 1, 7 »a omiljet će mi kuća Judina, spasit ću je Jahvom, Bogom njihovim, a neću je spasiti lukom, mačem ni kopljem, ni konjima ni konjanicima.'《; Hoš 1, 8 »Kad odoji Nemilu, zače opet i rodi sina.«; Hoš 1, 9 »I reče Jahve: 'Nadjeni mu ime Ne-narod-moj, jer više niste narod moj i ja vama nisam više Onaj koji jest.' «; Hoš 2, 3 »Recite braći svojoj: 'Narode moj', sestrama svojim:

\footnotetext{
${ }^{16}$ Usp. B. LUJIĆ, Starozavjetni proroci, Zagreb, ${ }^{22010 ., ~} 128$.

${ }^{17}$ Usp. I. DUGANDŽIĆ, Biblijska teologija Novoga zavjeta, Zagreb, 2004., 167.; I. Dugandžić u tom pogledu slijedi Joachima Gnilku; Usp. J. GNILKA, Teologija Novoga zavjeta, Zagreb, 1999., 357. Zanimljivo je primijetiti da Joachim Gnilka smatra da »lanac«starozavjetnih citata u 1 Pt 2, 6-10 nije prethodio autoru kao zbirka svjedočanstava, već je pisac sam sastavio ta svetopisamska mjesta, no ostaje upitno je li se pritom oslanjao na usmene predloške.

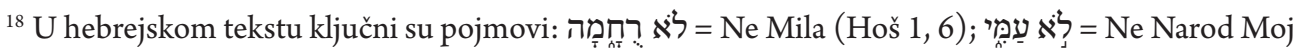

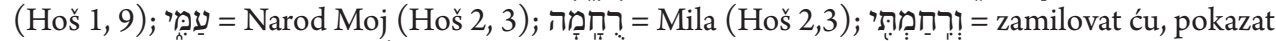
ću milosrđe (Hoš 2, 25); עַפְִ = ti (si) narod moj (Hoš 2, 25).
} 
'Mila.«; Hoš 2, 25 »I posijat ću ga u zemlji, zamilovat ću Nemilu, Ne-narodu mom reći ću: 'Ti si narod moj!' a on će reći: 'Bože moj!'«; - paralela s: 1 Pt 2, 10 »vi, nekoć Ne-narod, a sada Narod Božji; vi Ne-mili, a sada Mili.«

\section{Struktura teksta}

Perikopa 1 Pt 2, 4-10 sastoji se od sedam redaka koji se mogu podijeliti u tri skupine, čime perikopa dobiva sljedeću strukturu: I.) 1 Pt 2, 4.5 - u tom prvom dijelu govor je o novom duhovnom domu, a autor poslanice potiče na pristupanje kamenu živomu (tj. Isusu Kristu) i potiče na ugradnju u duhovni dom za sveto svećenstvo, za prinos duhovnih žrtava Bogu po Isusu Kristu; II.) 1 Pt 2, 6-8 - u tom drugom dijelu govor je o kamenu ugaonom (na Sionu), a autor poslanice upućuje na ispunjenje Izaijina proroštva (Iz 28, 16) u Isusu Kristu (tj. on je taj Kamen ugaoni). Autor ovdje sučeljava, kao u antitezi, one koji u Krista vjeruju i one koji ne vjeruju; III.) 1 Pt 2,9.10 - u tom trećem dijelu govor je o narodu Božjem, a autor navodi što su oni koji vjeruju, tj. rod izabrani, kraljevsko svećenstvo, sveti puk, stečeni narod pozvan k divnom svjetlu ..., nekoć Ne-narod, a sada Narod Božji, nekoć Ne-mili, a sada Mili (usp. Hoš 1, 6-9, Hoš 2, 3.25). Duhovni Dom, u koji se Kristovi vjernici kao sveto svećenstvo ugrađuju, može se označiti i kao skup onih koji u Krista vjeruju, kao Narod Božji. Stoga se može zaključiti da je središnji dio u kojem se govori o kamenu ugaonom, tj. o Isusu Kristu, uokviren govorom o Kristovim vjernicima i poticajima njima upućenima.

\section{Motivi}

U perikopi $1 \mathrm{Pt}$ 2, 4-10 postoji relativno mnogo riječi, tj. pojmova koje bi se moglo uzeti kao značajnije motive u razmatranju o teološkoj poruci same perikope. Uočljivo je da se dio tih pojmova pojavljuje samo jednom u cijeloj poslanici (hapax legomenon) i to upravo u toj perikopi. Važno je uočiti mjesta pojavljivanja pojedinoga motiva u poslanici i kontekst u kojem se motiv nalazi, zatim uočiti gramatički, tj. morfološki oblik same riječi i značenjsku promjenu koja morfološkom promjenom riječi nastaje te ponuditi zaključak o pojedinom motivu. Naposljetku se uočava koji od analiziranih motiva imaju veću teološku važnost za samu perikopu. Analizirani su sljedeći motivi: ${ }^{19}$ riječ, kamen, stijena, svećenstvo, žrtve, vjerovati, ne vjerovati, dom, (u)graditi, rod, puk, narod.

\footnotetext{
${ }^{19}$ Mnogi od tih motiva pripadaju starozavjetnim citatima unutar perikope, i stoga je njihov kontekst djelomično objašnjen u razjašnjavanju konteksta starozavjetnih citata, odnosno gore navedenih redaka iz starozavjetnih paralela.
} 


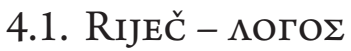

Motiv $\lambda$ ó ${ }^{\circ}$ nalazi se na šest mjesta u poslanici u različitim kontekstima i s različitim značenjima. U $1 \mathrm{Pt} 1,23$ spominje se novo rođenje iz neraspadljiva sjemena riječju Boga koji živi i ostaje, a to podsjeća na prispodobu o sijaču u sinoptičkim evanđeljima. U 1 Pt 2, 8 izraz »neposlušni Riječi« označava neposlušnost Kristu, odnosno nevjeru u Krista. U 1 Pt 3, 1 dvaput se pojavljuje izraz $\lambda$ ó $o \varsigma$ u svojevrsnoj igri riječima pri čemu prvi put izraz ima kristološko značenje, tj. označuje Krista, a drugi put ima osnovno značenje kao smisleni verbalni izrazi, odnosno riječi. Kontekst je u retku 3, 1 vezan uz ponašanje žena prema muževima s kojima su u braku. Muževi neposlušni Riječi, tj. Kristu, mogu biti pridobiveni (za Krista - Riječ) i bez riječi, tj. neverbalnim izražavanjem, nagovaranjem, poučavanjem i sl., i to bogoljubnim i čistim življenjem vlastitih žena. U 1 Pt 3, 15 upućen je poziv da se bude spreman na odgovor svakomu koji zatraži obrazloženje nade koja je »u vama «. Kako se izraz $\lambda$ ó $о \varsigma$ može prevesti s više od sto različitih hrvatskih riječi, u tom je retku preveden riječju »obrazloženje «. U $1 \mathrm{Pt} 4,5$ isti je izraz preveden riječju »račun «, u kontekstu raskalašenih pogana koji će polagati račun »Onomu tko je već spreman suditi žive i mrtve «. To je izraz koji je ušao u apostolsko vjerovanje $\mathrm{u}$ kristološkom

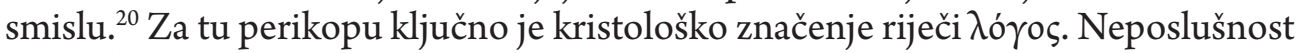
Riječi (logosu) može se tumačiti i kao nevjernost jer glagol ả $\pi \varepsilon \imath \varepsilon \dot{\varepsilon} \omega^{21}$ ima značenje 'ne poslušati, biti neposlušan', a u odnosu s Bogom 'biti nevjeran, nemati vjere, ne vjerovati' i sl. To su sve osobna, personalna, značenja vezana za osobu Isusa Krista koja se u retku 1 Pt 2, 5 izričito spominje i na tu osobu odnosi se i značenje riječi

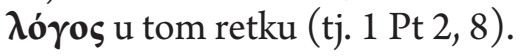

\subsection{KAMEN - $\Lambda I \Theta O \Sigma$ I STIJENA - ПETPA}

Motiv kamena pojavljuje se pet puta u toj perikopi, no ne spominje se na drugim mjestima u poslanici. U 1 Pt 2, 4 pojavljuje se kao $\lambda i \theta o v$ (A jd. m. r.) i odnosi se na Isusa Krista. $U$ spomenutom retku $(2,4)$ govori se o kamenu živom ( $\zeta \tilde{\omega} v \tau \alpha$, part. prez. akt.) kojega su ljudi odbacili, što se odnosi na Isusovu muku i smrt, a autor poslanice na to se vraća u perikopi o Kristu patniku (1 Pt 2, 21-25). Uočljivo je da autor spominje naslovnike (kojima poslanicu upućuje) da pristupaju $\mathrm{u}^{22}$ tomu $\gg$ kamenu koji živi«, čak uz intonaciju poticaja koji se u poslanici uočavaju u brojnim imperativima glagola. U 1 Pt 2, 5 motiv kamena pojavljuje se kao $\lambda i \theta_{o}$ ı $\zeta \tilde{\omega} v \tau \varepsilon \varsigma, ~ t j$ »živo kamenje « i označava same naslovnike koje autor potiče da se ugrađuju u

\footnotetext{
$20 \gg$ Isus Krist ( ... ) sjedi s desna Boga Oca Svemogućega, odonud će doći suditi žive i mrtve.«

${ }^{21}$ Usp. W. BAUER, F. W. DANKER, Greek-English Lexicon of the NT (BDAG), u: BibleWorks 9., Lexicons.

${ }^{22} \mathrm{Tj}$. koji pristupate, pristupajući; $\pi \rho \circ \sigma \varepsilon \chi \chi o ́ \mu \varepsilon v o l$, part. prez. med.
} 
»duhovni Dom za sveto svećenstvo«. U 1 Pt 2, 6 isti motiv kamena pojavljuje se također u kristološkom smislu, tj. »na Sionu kamen odabrani, dragocjeni kamen ugaoni « predstavlja Krista, a starozavjetni paralelizam nalazi se u proroka Izaije (Iz 28, 16). U $1 \mathrm{Pt} 2,7-8$ motiv kamen spominje se još tri puta i odnosi se također na Krista, ali je pritom primijenjen antitetički paralelizam u formi: a.) koji vjerujete

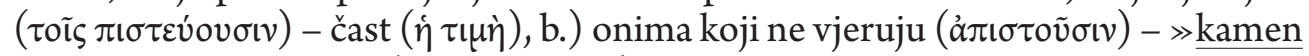
koji odbaciše graditelji (oni koji grade) postade kamen zaglavni i kamen spoticanja, stijena posrtanja $\ll$. U tom drugom dijelu antitetičkoga paralelizma uočljiv je jedan sinonimni paralelizam »kamen $\left(\lambda i \theta_{\circ} \varsigma\right)$ - stijena $(\pi \dot{\varepsilon} \tau \rho \alpha)$ 《, iz čega se može zaključiti da je u perikopi prisutna razvijenija stilska forma. Sadržajno $1 \mathrm{Pt}$ 2, 7-8 podsjeća i na Ps 118, $22(117,22)$, na Petrov govor u Djelima apostolskim (Dj 4, 11) i na perikopu o vinogradarima ubojicama u sinoptičkim evanđeljima, što može biti značajno za daljnju egzegetsku analizu (usp.: 1 Pt 2, 7-8; Mt 21, 42; Mk 12, 10-11; Lk 20, 17). Kamen zaglavni, kamen spoticanja i stijena posrtanja dodatna su tri kristološka naslova koji ukazuju na to da je upravo taj »kamen koji odbaciše graditelji $\ll$, tj. Isus Krist, conditio sine qua non za svako od obećanja navedenih u $1 \mathrm{Pt}$

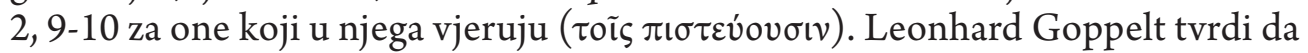
u najneposredniji dodir 1 Pt 2, 4s. dolaze izrazi kumranskih tekstova, koji motiv kamena iz Iz 28, 16 povezuju sa slikom građevine, a oboje se odnosi pritom na eshatološku zajednicu. U Novom zavjetu jedino takvo mjesto, prema Goppeltu, ${ }^{23}$ koje također povezuje »ugaoni kamen « iz Iz 28, 16 s građevinom zajednice jest Ef 2, 20 ( $\gg$ nazidani na temelju apostola i proroka, a zaglavni je kamen sam Krist Isus «). Krist je temelj univerzalne građevine jer Prva Petrova poslanica gleda u eshatološkom smislu na univerzalni način ${ }^{24}$ na Krista koji je kao »ugaoni kamen « svima postavljen na putu, a ne samo malobrojnima koji su ga izabrali za vlastiti temelj. Motiv stijene ( $\pi \dot{\varepsilon} \tau \rho \alpha$ ) pojavljuje se u poslanici samo u $1 \mathrm{Pt} 2,8$ i to kao paralelizam »kamen spoticanja, stijena posrtanja « za one koji su Kristu nevjerni, tj. neposlušni Riječi. Uočljivo je da se isti paralelizam nalazi i u Rim 9, 33 (»Evo postavljam na Sionu kamen spoticanja i stijenu ${ }^{25}$ posrtanja «), i Iz 8, 14 ( $\gg \mathrm{On}^{26}$ će vam biti zamka i kamen spoticanja i stijena posrtanja «). Karl Hermann Schelkle u svojem komentaru Prve Petrove poslanice spominje kumranske nalaze u špilji broj 4. gdje je pronađen niz mesijanskih tekstova, za koje se pretpostavlja da sačinjavaju mesijanski starozavjetni florilegij kumranske zajednice. Pronađen je i citat Iz 28, 16 u 1 QS 8, 7, no, naravno, nisu pronađeni citati $1 \mathrm{Pt}$

\footnotetext{
${ }^{23}$ Usp. L. GOPPELT, Der Erste Petrusbrief, Göttingen, ${ }^{8} 1978 ., 143$.

${ }^{24}$ Usp. isto, 149.-150.

${ }^{25}$ U kristološkom smislu, tj. Pavao misli na Krista.

${ }^{26} \mathrm{Tj}$. Jahve nad vojskama.
} 
2, 6-8, stoga Schelkle ${ }^{27}$ zaključuje da su se podudarnosti među tekstovima $1 \mathrm{Pt} 2$, 6-8, Rim 9, 33 i Iz 28, 16 pojavile vjerojatno zbog pripremljenih sažetaka mesijanskih proročanstava o Mesiji kao $\gg$ temeljnom kamenu « koje su preradile rabinske škole u svojoj egzegetskoj praksi te utjecale na podudarnost i nastanak tekstova 1 Pt 2, 6-8 i Rim 9, 33. Ključni izrazi iz grčkih tekstova upravo spomenutih redaka s (ne doslovnim) prijevodom iz zagrebačke Biblije mogu se prikazati na sljedeći

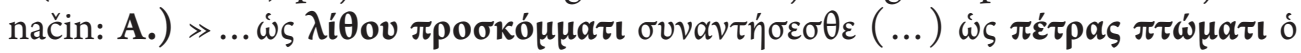

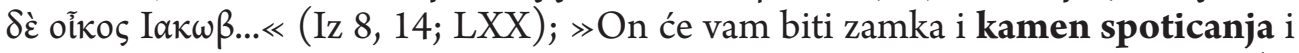
stijena posrtanja za obje kuće Izraelove, zamka i mreža svim Jeruzalemcima.« (Iz

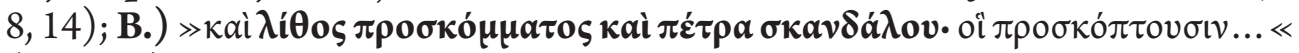
(1 Pt 2, 8); »i kamen spoticanja, stijena posrtanja; oni se o nj spotiču, neposluš-

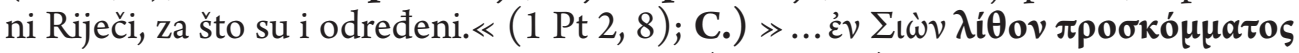

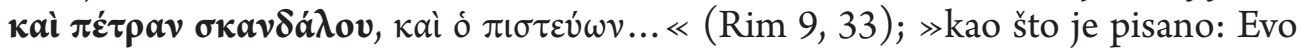
postavljam na Sionu kamen spoticanja i stijenu posrtanja. Ali tko u nj vjeruje, neće se postidjeti.« (Rim 9, 33). Ako se izrazi kamen (lithos) i stijena (petra) zbog sličnoga značenja ovdje uzmu u razmatranje kao paralelizmi, onda ni sintagme kamen spoticanja i stijena posrtanja ne bi trebalo uzeti kao semantički suprotstavljene izraze, već kao sintagme koje ukazuju na istu stvarnost. U Iz 8, 14 Septuaginta do-

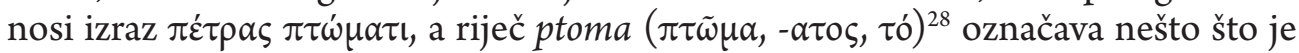
palo, propalo (npr. mrtvo tijelo i sl.), metaforički kao propast, grijeh, uništenost. Izraz skandalon povezan je uz riječ stijena - petra u $1 \mathrm{Pt} 2,8 \mathrm{i}$ u Rim 9, 33, a značenje

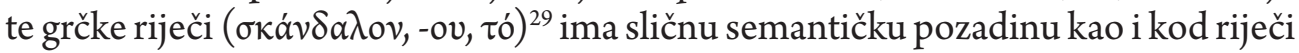
ptoma, tj. označava zamku ili dio zamke o koji se netko spotiče, nešto što uzrokuje pad čovjeka, propast, metaforički kao grijeh ili napast i slično. Treći par riječi jest

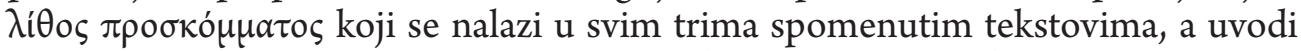

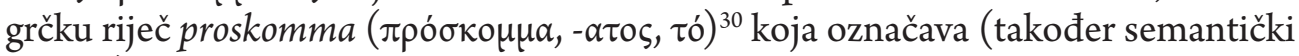
srodno) posrtanje, prepreku, smetnju, zapreku, priliku da se čini krivo, spoticanje i sl. Stječe se dojam kao da se tim trima parovima, lithos proskommatos, petra skandalou i petra ptomatos, htjelo izreći istu stvarnost, samo uz dvostruko naglašavanje, potvrđivanje, ponavljanje i dodatno isticanje. Pavao u poslanici Rimljanima poseže za istim starozavjetnim tekstom kao i autor Prve Petrove poslanice, obojica tumačeći izraze lithos proskommatos i petra skandalou u kristološkom smislu (tj. Krist je kamen spoticanja i stijena posrtanja), dok bi se Izaijin tekst (Iz 8, 14) doslovno mo-

\footnotetext{
${ }^{27}$ Usp. K. H. SCHELKLE, Die Petrusbriefe; Der Judasbrief; Auslegung von Karl Herman Schelkle, Freiburg im Breisgau, 1980., 62.

${ }^{28}$ Usp. W. BAUER, F. W. DANKER, Greek-English Lexicon of the NT (BDAG); Usp. J. H. THAYER, Greek-English Lexicon of the NT, u: BibleWorks 9., Lexicons.

${ }^{29}$ Usp. W. BAUER, F. W. DANKER, Greek-English Lexicon of the NT (BDAG).

${ }^{30}$ Usp. isto.
} 
gao tumačiti u patriološkom smislu (tj. Bog Otac, Jahve nad vojskama jest kamen spoticanja i stijena posrtanja) jer na to izvorni kontekst starozavjetne perikope (Iz $8,11-15)$ upućuje. Važno je uočiti da tekst perikope ukazuje na vjeru (tj. vjerovati, pisteuo) i poslušnost Riječi ( $\mathrm{tj}$. Logosu) jer oni koji to ne posjeduju ne će baštiniti

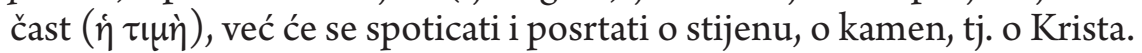

\subsection{SveĆENSTVO - IEPATEYMA}

Motiv svećenstva nalazi se u poslanici na dvama mjestima i oba su u toj perikopi.

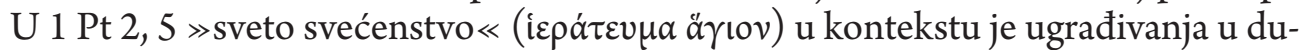

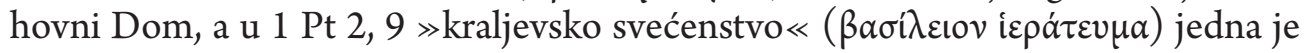
od odrednica onih koji vjeruju u Krista, na što upućuju izrazi u 1 Pt 2, 6 »tko u nj vjeruje « i u 1 Pt 2, 7 »vama dakle koji vjerujete «. Izraz kraljevsko svećenstvo podsjeća na Božje obećanje za Izraelce ako budu držali Božji Savez u Izl 19, 6 (»vi ćete mi biti kraljevstvo svećenika, narod svet.' Tim riječima oslovi Izraelce.«). U poslanici ima više mjesta iz kojih bi se moglo zaključiti da autor poslanicu piše za judeokršćane (npr. »Sarina djeca « u 1 Pt 3, 6 ili »raseljeništvo $\ll$ u 1 Pt 1, 1), ali i mjesta koja ukazuju da je upućena kršćanima iz poganstva (npr. »isprazan način života što vam ga oci namriješe « u $1 \mathrm{Pt} 1,18$ ili za neke egzegete npr. »Vi, nekoć Ne-narod, a sada Narod Božji « u $1 \mathrm{Pt} 2,10)$. Ipak, ostaje ključna kod motiva svećenstva u toj perikopi pripadnost Kristu po vjeri u njega, a ne pripadnost židovskom narodu, i ne svećenstvo kao pojedinačni osobni poziv, već više u smislu sveopćega svećenstva vjerničkoga naroda. ${ }^{31}$ Autor poslanice postavlja kao ključnu stvarnost vjerovati u Isusa Krista, izravno se obraćajući naslovnicima poslanice koji vjeruju, te stoga i mogu prinositi duhovne žrtve, ugodne Bogu po Isusu Kristu, kao sveto svećenstvo.

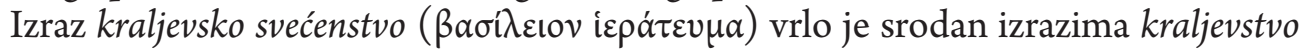

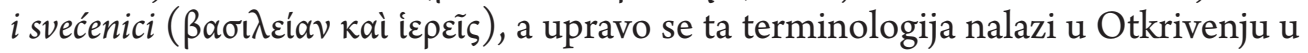
dvjema perikopama: u retku Otk 1, 6 i u retku Otk 5, 10. U Otk 20, 6 spominju se

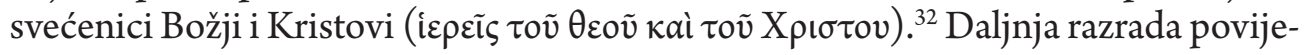

\footnotetext{
${ }^{31}$ Mnoge doktrinarne rasprave vezane uz pitanje razlikovanja ministerijalnoga i općega (krsnoga) svećenstva vodile su se zbog razlike u značenju između grčke riječi i̊pev́s (hiereus) koja znači posvećen, svet, (starozavjetni) svećenik koji prinosi Bogu životinjske žrtve kao tzv. hebr. kohen / pl. kohanim - כָּּּן, kultni svećenik koji predsjeda u božanskom kultu (čak neovisno je li riječ o poganskom kultu ili starozavjetnom izraelskom kultu) i grčke riječi $\pi \rho \varepsilon \sigma \beta v ́ \tau \varepsilon \rho o \varsigma$ (presbyteros) koja znači starješina, stariji (tj. čovjek poodmakle dobi), stariji (npr. od dva sina onaj stariji), starac, star (kao pridjev), u SZ-u židovski religijski vođe, u NZ-u religijski vođe kršćanskih zajednica, tj. crkveni vođe. Obje se riječi vrlo često bez razlike prevode na različite jezike riječju 'svećenik'.

32 Značajno je da riječ hiereus pronalazi u Novom zavjetu svoje mjesto u Lk 1, 5 u kontekstu svećenika

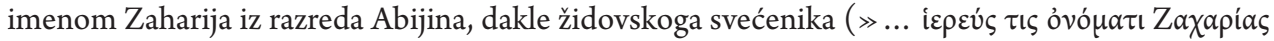

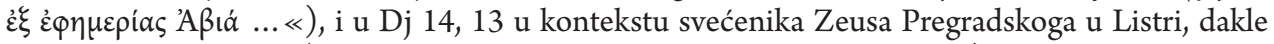

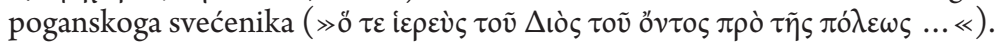


sti djelovanja (tzv. Wirkungsgeschichte) te perikope dotiče se teme odnosa ministerijalnoga i općega (krsnoga) svećenstva, kao i usporedbe grčkih izraza presbyteros, hiereus, hierateuma, sympresbyteros i drugih srodnih izraza.

\section{4. ŽRTVE -}

Motiv žrtava pojavljuje se u poslanici samo jednom u $1 \mathrm{Pt}$ 2, 5 kao duhovne žrtve,

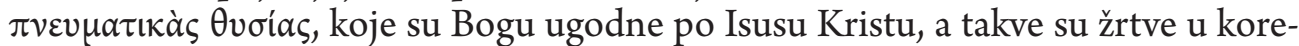
laciji s duhovnim Domom u kojemu vjernici kao sveto svećenstvo trebaju prinositi prikladne žrtve, dakle duhovne. Prinošenje duhovnih žrtava Bogu djelatnost je svećenika, ali svećenstvo je sada cijeli narod Božji, zajednica vjernika. U tom kontekstu trebalo bi razlikovati izraz presbyteros od u toj perikopi spomenutoga izraza hierateuma, osobito s obzirom na uloge, starozavjetnu ili (post)novozavjetnu pozadinu, vrstu žrtava koje se prinose i sl. Alan B. Stibbs ${ }^{33}$ spominje da duhovne žrtve koje se prinose sada $(\nu \tilde{v} v)$ nisu ceremonijalne ili životinjske, već moralne i duhovne, te da su starozavjetne žrtve stalno postavljale pitanje hoće li žrtva (tj. ceremonijalno žrtvovanje životinja) biti prihvaćena, što se u Heb 10, 1-10 negira. Stibbs u komentaru te perikope tvrdi da je Bogu ugodna žrtva slobodno izabrana osobna odanost koju životinje ne mogu postići jer je riječ o voljnoj, misaonoj i moralnoj poslušnosti, a kršćani, tj. oni koji su Kristu pristupili, mogu biti sigurni da će njihova žrtva, po Kristu prinesena, biti primljena. Hubert Frankemölle u svome komentaru Prve Petrove poslanice ${ }^{34}$ tvrdi da se u skladu s kontekstom 1 Pt 2, 4-10 »duhovne žrtve « trebaju interpretirati sociološko-etički. Upravo po duhovnim žrtvama grade kršćani s Isusom Kristom i po njemu jedinstvo i postaju kao i Krist »Bogu ugodni «. Duhovne žrtve prema Frankemölleu stoje jasno u suprotnosti s 1 Pt 2, 1 (tj. zloće, prijevare, himbe i zavisti i sva klevetanja koje treba ostaviti) i $1 \mathrm{Pt}$ 2, 8 (spoticanje o kamen zaglavni i neposlušnost Riječi, tj. Kristu).

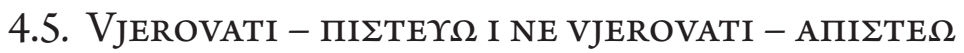

Glagol $\pi ı \sigma \tau \varepsilon v ́ \omega$ nalazi se na trima mjestima u poslanici u participu prezenta aktivnoga $(\pi เ \sigma \tau \varepsilon v ́ \omega v)$ i time označuje 'one koji vjeruju', što je semantički sukladno

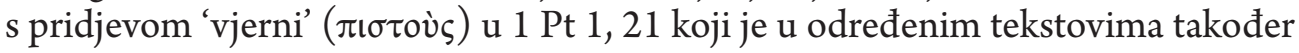
zamijenjen oblikom participa. U 1 Pt 1, 8 govori se o onima koji u Krista vjeruju te klikću od radosti što postigoše svrhu svoje vjere: spasenje duša. U $1 \mathrm{Pt}$ 2, 7 govori se

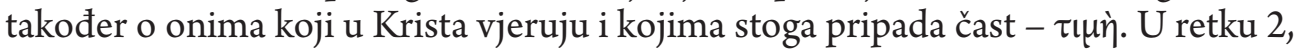
6 navedeno je kako stoji u Pismu da onaj koji vjeruje u kamen ugaoni na Sionu, tj. u Krista, ne će biti postiđen. Vjerovati u Krista potrebno je da bi oni kojima je posla-

\footnotetext{
${ }^{33}$ Usp. A. M. STIBBS, Prva Petrova. Uvod i komentar, Novi Sad, 1989., 72.-73.

${ }^{34}$ Usp. H. FRANKEMÖLLE, 1.Petrusbrief. 2.Petrusbrief. Judasbrief, Würzburg, ${ }^{2}$ 1990., 42.
} 
nica upućena postigli svoj poziv kao rod izabrani, kraljevsko svećenstvo, sveti puk, narod stečeni, narod Božji, oni koji su mili Bogu (1 Pt 2, 9-10). Pridjevom 'vjerni' u 1 Pt 1, 21 označava se one koji po Kristu vjeruju u Boga, a u istom retku autor poslanice znakovito dodaje: $\gg$ Bog koji ga uskrisi od mrtvih te mu dade slavu da vjera vaša i nada bude u Bogu. $\ll^{35}$ Glagol $\alpha \dot{\jmath} \iota \sigma \tau \dot{\varepsilon} \omega$ nalazi se u poslanici samo u retku

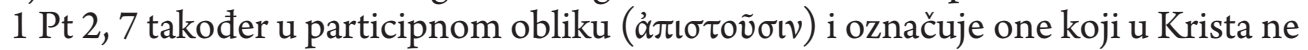
vjeruju, što je u antitezi s Kristovim vjernicima. Posljedica je njihova nevjerovanja spoticanje o kamen zaglavni, tj. Krista, jer su neposlušni (ả $\pi \varepsilon \bullet \theta o \tilde{v} v \tau \varepsilon \varsigma)$ Riječi. Riječ ( $\tau \tilde{\omega} \boldsymbol{\lambda} \lambda \hat{\gamma} \gamma($ ) je ovdje u korelaciji s Kristom, tj. odnosi se na Krista, što podsjeća na ivanovsku teologiju o Kristu - Logosu. Oni koji ne vjeruju (å dje nisu precizirani jer nedostaje određeni član, ${ }^{36}$ te se stoga može zaključiti da se misli općenito na nevjernike s obzirom na vjeru u Krista.

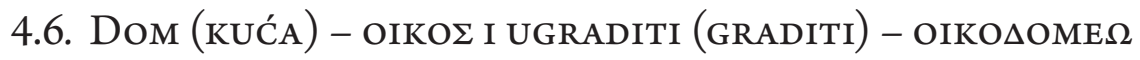

Motiv doma nalazi se u Prvoj Petrovoj poslanici na dvama mjestima, prvo u toj

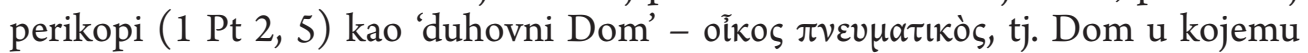
Duh Sveti obitava i izgrađuje ga, a u koji se Kristovi vjernici pozivaju da se u njega ugrađuju kao živo kamenje. Na drugom mjestu u poslanici u $1 \mathrm{Pt} 4,17$ taj je motiv

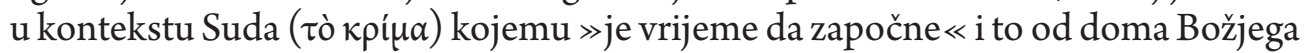

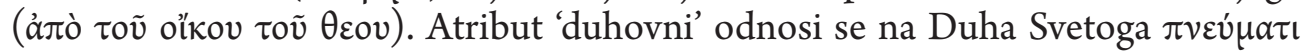

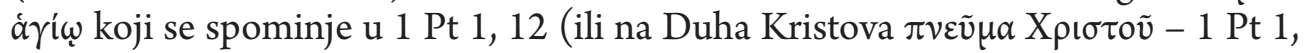

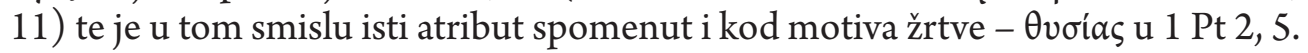
Riječ oĩkos ovdje je prikladnije prevesti s 'dom' u malo uzvišenijem smislu nego kao uobičajeno obitavalište, tj. kuća (oikía), jer se ovdje misli na prebivalište Božje, prebivalište Duha, a u toj perikopi izražen je poticaj da se vjernici u taj Dom ugrađuju, da bi kao sveto svećenstvo prinosili žrtve duhovne, ugodne Bogu po Isusu Kristu.

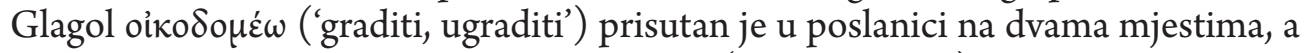
oba su u toj perikopi. U $1 \mathrm{Pt} 2,5$ oiko $\delta$ o $\varepsilon \tilde{\sigma} \sigma \theta \varepsilon$ (imp. prez. pas.) ukazuje na poticanje ili čak zapovijedanje: »ugrađujte se u duhovni Dom za sveto svećenstvo.« U $1 \mathrm{Pt}$

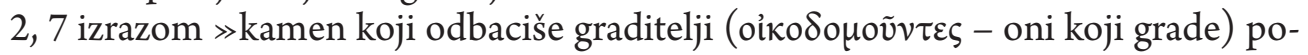
stade kamen zaglavni « koristi se participni oblik glagola, ali je glagol primijenjen u kontekstu onih koji odbacuju Krista. Graditi se može konstruktivno s Kristom i za Krista (redak 2, 5) ili nekonstruktivno odbacujući Krista (redak 2, 7), a to dvoje u isključivoj je suprotnosti, te se stoga zahtijeva opredjeljenje za Krista, da sve

\footnotetext{
${ }^{35}$ Pojmovi vjera, vjeran i vjerovati tematski su i teološki važni u Prvoj Petrovoj poslanici.

${ }^{36}$ Usp. A. M. STIBBS, Prva Petrova, 75.
} 
bude izgrađujuće, a ne destruktivno. Novi zavjet tome sukladnu sliku ${ }^{37}$ pronalazi u Otkrivenju gdje Sveti, Istiniti, Onaj koji ima ključ Davidov govori anđelu Crkve u Filadelfiji: $\gg$ Pobjednika ću postaviti ${ }^{38}$ stupom u hramu Boga moga i odande on više neće izići i napisat ću na njemu ime Boga svoga i ime grada Boga svoga, novog Jeruzalema koji siđe s neba od Boga mojega, i ime moje novo.«(Otk 3, 12) Cilj koji se u toj perikopi Prve Petrove poslanice nameće kršćaninu nije da on postane puki graditelj, već da bude »građevni materijal «, ontološki ili esencijalno prikladan za izgradnju duhovnoga Doma (oĩ ki da iz njega više ne izlazi kada je već u njega ugrađen i da prinosi duhovne žrtve, ugodne Bogu po Isusu Kristu.

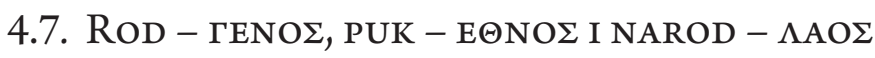

Motiv roda blisko je povezan s motivima puka i naroda u retku $1 \mathrm{Pt} 2$, 9 što je, uostalom, i jedino mjesto gdje se taj motiv pojavljuje u poslanici. Rod izabrani ( $\gamma \varepsilon \dot{v} o \varsigma$

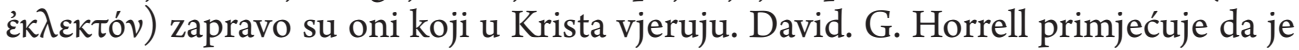

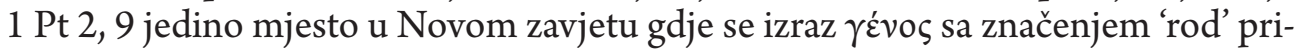
mjenjuje na Crkvu. On ističe da se u židovskim spisima, tj. u Septuaginti izrazom rod (genos) označavalo izraelski narod, ${ }^{39}$ no kasnije se tim izrazom običava nazivati kršćane kao treći narod uz Židove i pogane. ${ }^{40}$ Motiv puka ( $\left.\varepsilon^{\prime} \theta v o \varsigma\right)$ nalazi se u po-

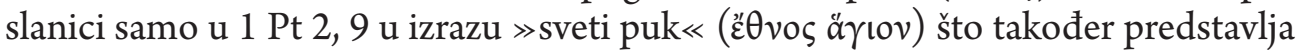
one koji u Krista vjeruju, tj. kršćane. Tom se riječju često nazivaju poganski narodi (u Septuaginti) ili nekršćani u novozavjetnim tekstovima, ali je ovdje izraz dobio pozitivno značenje. U Starom zavjetu (LXX) sintagma »sveti puk« $(\ddot{\varepsilon} \theta$ vos $\ddot{\alpha} \gamma ı v)$ relativno je rijetko zastupljena (npr. Izl 19, 6; 23, 22; Mudr 17, 2), no u Levitskom zakoniku dosta je zastupljena tema poziva Izraelu da bude svet ('budite sveti!' -

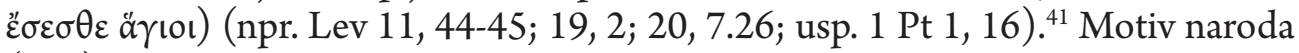
(laos) nalazi se u poslanici samo u dvama susjednim redcima, u 1 Pt 2, 9-10 kao

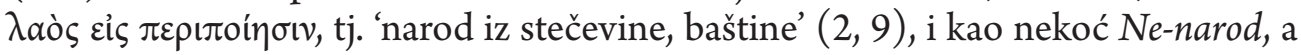

\footnotetext{
${ }^{37} \mathrm{~K}$ tomu valja zamijetiti da autor poslanice na tome mjestu poseže i za slikom koja je bila živo i duboko utisnuta u čovjeka helenističkoga svijeta. Primjer toga jesu Karijatide s Erehtejona atenske Akropole iz 5. st. pr. Kr., dakle ženski kameni likovi koji stojeći obrubljuju hram kao noseći stupovi.

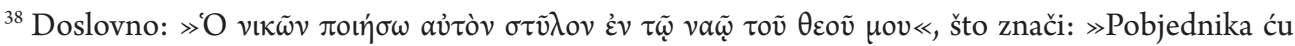
učiniti stupom u hramu Boga moga.« Tu je dakle radnja činjenje ( $\left.\pi \circ \imath^{\prime} \sigma \omega\right)$, a ne postavljanje ili

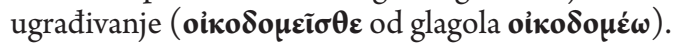

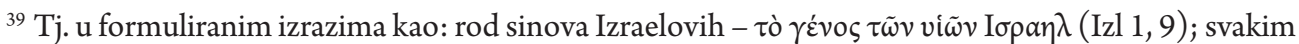

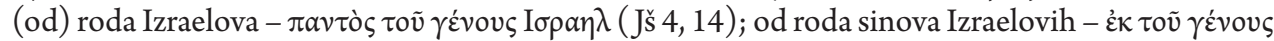
$\tau \tilde{\omega} \nu$ vi $\tilde{\omega} v \operatorname{I\sigma } \rho{ }^{\prime} \eta \lambda(\mathrm{Dn} 1,6)$.

${ }^{40}$ Usp. D. G. HORRELL, 1 Peter, New York, 2008., 71.

${ }^{41}$ Usp. isto, 71.
} 
sada Narod Božji $(2,10)$ što podsjeća na proroka Hošeu i simbolična imena njegove djece (Hoš $1,6-9 ; 2,3.25)$. Tom se riječju u Septuaginti naziva izraelski narod, dakle izabrani narod Božji, a u Novom zavjetu tom riječju označeni su kršćani kao novi narod Božji. U Starom zavjetu, kako primjećuje D. G. Horrell, opisivanje naroda kao laos uobičajeno je u izrazima kao $\gg \operatorname{moj}$ narod $\ll$ ili $\gg$ tvoj narod $\ll$, gdje taj narod pripada Bogu ${ }^{42}$ Motivi roda, puka i naroda nalaze se u perikopi u kontekstu gore već spomenutih starozavjetnih citata.

\section{Daljnja egzegetska i biblijsko-teološka analiza perikope 1 Pt 2, 4-10}

U knjizi 1 Peter David G. Horrell u svojem komentaru te perikope bilježi da je taj osobito zahtjevan i egzegetski proučavan tekst koherentno složen od nekoliko utkanih biblijskih tekstova. ${ }^{43}$ Način na koji je autor poslanice citirao i interpretirao te tekstove u perikopi ima, prema Horrellu, određenu sličnost sa židovskim midrašem, osobito s pešarimom ${ }^{44}$ iz Qumrana, a primjer za to je pešer psalama iz Qumrana 4Q171 u kojem se stih određenoga psalma citira, potom tumači (u sljedećem stihu), onda se sljedeći stih psalma citira i zatim tumači te tako naizmjenično. Horrell u redcima 6, 7 i 8 perikope vidi sličnu tehniku zajedničkoga povezivanja i tumačenja, tj. komentiranja različitih tekstova povezanih zajedničkom ključnom riječju (ovdje je to kamen - lithos), što je bilo prisutno u onodobnoj židovskoj egzegetskoj praksi. Uz novozavjetne paralele mesijanskih tekstova s motivom kamena (lithos) kao u Mk 12, 10-11; Mt 21, 42; Lk 20, 17; Dj 4, 11; Rim 9, 32-33, postoje i kod zajednice u Qumranu slične paralele u korištenju takvih slika za iskazivanje eshatoloških očekivanja zajednice, no, kako David Horrell primjećuje, ${ }^{45}$ autor poslanice stavlja u toj perikopi tri takva teksta zajedno radi opisa Kristova identiteta i sudbine, što je jedinstveno u Novom zavjetu. Pregledno se to može prikazati na sljedeći način: ${ }^{46}$ A.) Uvodna formula: $\gg$ Stoga stoji u Pismu: «(1 Pt 2, 6a); B.) Prvi citat: $\gg$ Evo postavljam na Sionu kamen odabrani, dragocjeni kamen ugaoni: Tko u nj vjeruje, ne, neće se postidjeti.« (Iz 28, 16; LXX); C.) Komentar: »Vama dakle koji vjerujete - čast! A onima koji ne vjeruju « (1 Pt 2, 7a); D.) Drugi citat: »kamen koji odbaciše graditelji postade kamen zaglavni« (Ps 118, 22/117, 22);

\footnotetext{
${ }^{42}$ Npr.: Izl 33, 16; 2 Sam 7, 23; 1 Kr 8, 43; Iz 64, 8; Usp. D. G. HORRELL, 1 Peter, 71.

${ }^{43}$ Usp. D. G. HORRELL, 1 Peter, 68.-73.

${ }^{44} \mathrm{Tj}$. tumačenjima i raznim interpretacijama, npr. na Hošeu, Izaiju, psalme, itd.

${ }^{45}$ Usp. D. G. HORRELL, 1 Peter, 70.

${ }^{46}$ Usp. isto, 69.
} 
E.) Treći citat: $\gg$ i kamen spoticanja, stijena posrtanja « $(\mathrm{Iz} 8,14)$; F. $)$ Komentar: >oni se o nj spotiču, neposlušni Riječi, za što su i određeni.« (1 Pt 2, 8b). ${ }^{47}$

Vezano uz ekleziološku relevantnost te perikope u Prvoj Petrovoj poslanici i općenito u Novom zavjetu Douglas Karel Harink smatra da je apostol Petar kratku skicu

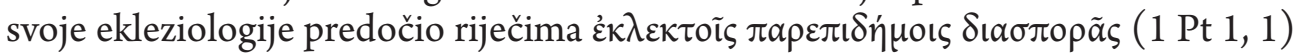
'izabranima raseljenicima dijaspore' u $1 \mathrm{Pt} 1,1 \mathrm{~b}$, no u toj je perikopi $(1 \mathrm{Pt} 2,4-10)$ tu ekleziološku skicu proširio da se oštrije i dublje razabire temelj, postojanje, bit i svrha Crkve, citirajući pritom Eugenea M. Boringa: »Ovaj odlomak predstavlja jednu od najgušćih konstelacija eklezioloških slika unutar Novog zavjeta. ${ }^{48}$ D. Harink u perikopi značajan motiv stijene (lithos) povezuje, iz perspektive starozavjetnih tekstova u perikopi, s Jahve, Bogom Izraelovim, dok iz perspektive Petrova jasnoga identificiranja Krista kao te stijene, Harink tu vidi jasno svjedočenje o božanskom identitetu Isusa Krista. Moglo bi se stoga iz egzegetske perspektive u toj perikopi nazrijeti dogmatsku kristološku istinu o božanskom identitetu Isusa Krista (»što ga ljudi odbaciše «; 1 Pt 2, 4), dakle njegovo božanstvo i čovještvo, makar to bilo samo implicitno u perikopi izraženo. S obzirom na kristološko tumačenje motiva stijene (petra) i kamena (lithos), Krist je nesumnjivo već došao jer je bio odbačen od ljudi, a to povezuje tu perikopu s već spomenutim sinoptičkim paralelama $\mathrm{u}$ prispodobi o vinogradarima ubojicama (Mt 21, 42; Mk 12, 10-11; Lk 20, 17), kao i s prologom Ivanova evanđelja: »bijaše na svijetu i svijet po njemu posta i svijet ga ne upozna. K svojima dođe i njegovi ga ne primiše.« (Iv 1, 10-11) No premda

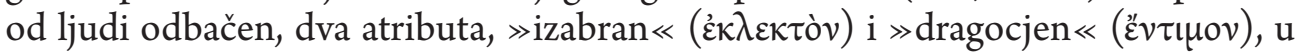
$1 \mathrm{Pt}$ 2, 4.6 svjedoče o Kristovoj povezanosti s Bogom, što opet povezuje perikopu, iz te perspektive, s drugim mesijanskim starozavjetnim tekstovima kao i brojnim novozavjetnim. ${ }^{49}$ Douglas Harink ne zanemaruje pritom ni važnost motiva kamen $z ̌ i v i(\lambda i \theta$ ov $\zeta \tilde{\omega} v \tau \alpha-1 \mathrm{Pt} 2,4)$ koji označava Krista, u korelaciji sa živo kamenje ( $\lambda$ iӨo $\zeta \tilde{\omega} v \tau \varepsilon \varsigma-1 \mathrm{Pt} 2,5$ ), tj. s kršćanima, pri čemu je ključna riječ glagol živjeti (grč. 乌̧áw, ovdje u participnom obliku) jer oni koji žive zapravo participiraju na životnosti i

\footnotetext{
${ }^{47} \mathrm{~S}$ obzirom na povezivanje citata iz različitih starozavjetnih knjiga, ali ne bezuvjetno i njihov izbor primjerice vezano uz temu kamen (lithos), Norbert Brox smatra da kod te perikope nije riječ o skupu svjedočanstava ili o nekom tekstualnom predlošku koji je jednostavno preuzet u perikopu, već je autor sam utkao različite citate na vlastiti način, što pokazuje posljedični i povezani slijed misli u perikopi i s obzirom na njezin položaj u poslanici. Usp. N. BROX, Der erste Petrusbrief, Zürich-Einsiedeln-Köln-Neukirchen-Vluyn, 1979., 95.

${ }^{48}$ Usp. D. K. HARINK, 1 \&2 Peter, Grand Rapids, 2009., 66.

${ }^{49}$ Usp. Iz 42, 1: »Evo Sluge mojega koga podupirem, mog izabranika, miljenika duše moje. Na njega sam svoga duha izlio da donosi pravo narodima.«; usp. Mt 3, 17; 17, 5.
} 
životu koji im se po Kristu ${ }^{50}$ daje, tj. na njegovoj životnoj stvarnosti. ${ }^{51}$ Kršćani stoga

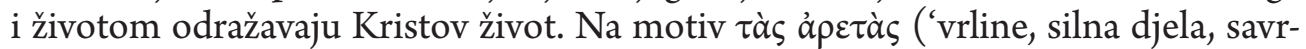
šenstva') iz 1 Pt 2, 9 posebno se osvrnuo Donald G. Miller ${ }^{52}$ iznoseći zapažanje da se ta riječ u perikopi pojavljuje u množini i označava 'divna djela, ${ }^{53}$ a u Novom zavjetu ta se riječ pojavljuje na još trima mjestima gdje označava 'kreposti'. Prema D. G. Milleru autor poslanice ovdje se približava (Deutero)Izaiji od kojega preuzima

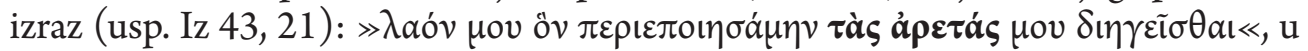
prijevodu: »narod koji sam sebi sazdao moju će kazivati hvalu! « To bi značilo da se iskazivanjem hvale Bogu ujedno iskazuju Božje vrline, tj. kreposti, no ono što je vjerojatnije, prema Millerovu mišljenju, jest da je Petar, odnosno autor poslanice, imao na umu očitovanje božanske moći, što bi uključivalo sve što je Bog kao Spa-

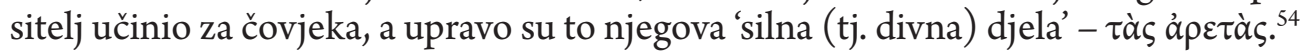

Erich Zenger ${ }^{55}$ smatra da u psalmu Ps 118 (117), u retku 22. gdje se spominje kamen zaglavni, upravo ta metafora kamena zaglavnoga označava početni i temeljni kamen kojim započinje gradnja građevine, kao na kamenu temeljcu na kojem je nošena cijela težina građevine. ${ }^{56}$ Zenger se ne slaže s time (kako smatraju pojedini egzegete) da taj kamen zaglavni predstavlja kamen kojim se gradnja završava, tj. kao neki finalni kamen na završetku gradnje. Ugaoni kamen posebno je isklesan kamen koji povezuje temelj s dvama zidovima koji se u temelju sastaju i on određuje stanje i veličinu građevine kojoj upravo taj ugaoni kamen stoji u temelju. U $1 \mathrm{Pt}$ 2, 6 ugaoni kamen predstavljen je i kao istodobno temeljni kamen. O tome ovisi, smatra Zenger, čvrsto utemeljenje kuće, osobito onda kada je kuća izgrađena od cigala na čvrstom kamenju. Suprotno takvom mišljenju Alan B. Stibbs smatra da se dragocjeni kamen ugaoni (Iz 28, 16; LXX), citiran u r. 2, 6 perikope, prikladnije

\footnotetext{
${ }^{50}$ Usp. motiv život ( $\dot{\eta} \zeta \omega \eta \dot{)}$ u Corpus Ioanneum osobito u Ivanovu evanđelju Iv 11, 25 prije perikope

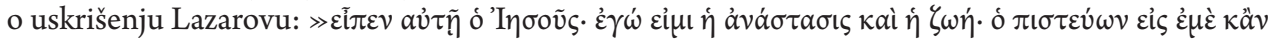

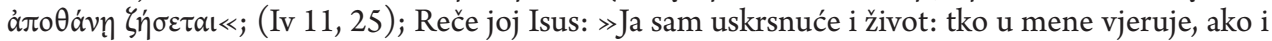

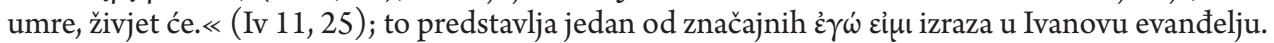

${ }^{51}$ Usp. D. K. HARINK, 1 \& 2 Peter, 68.

${ }^{52}$ Usp. D. G. MILLER, On this rock. A commentary on First Peter, Allison Park - Pennsylvania, 1993., 199.

${ }^{53}$ Karl Hermann Schelkle također ukazuje u svome komentaru Prve Petrove poslanice da su $\tau \grave{\alpha} \varsigma$

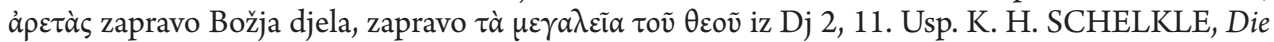
Petrusbriefe; Der Judasbrief; Auslegung von Karl Herman Schelkle, Freiburg im Breisgau, 1980., 65.

${ }^{54}$ Usp. D. G. MILLER, On this rock, 199.

${ }^{55}$ Erich Zenger u svom je četverosveščanom djelu Psalmen. Auslegungen u drugom svesku tumačio Ps 118 (117) i komentirao r. 22 psalma koji je relevantan za hermeneutiku te perikope (1 Pt 2, 4-10). Usp. E. ZENGER, Psalmen. Auslegungen, II., Freiburg-Basel-Wien, 2003., 112.-123.

${ }^{56}$ Usp. E. ZENGER, Psalmen. Auslegungen, II., 122.
} 
tumači kao glavni ili dragocjeni kamen, a ne temeljni kamen, jer za Krista je prikladnije slikovito reći da je egzaltiran na vrhu nove zgrade nego da je on temelj na dnu te zgrade. Stibbs ${ }^{57}$ ovdje poseže za deuteropavlovskom ekleziološkom slikom iz Ef 1, 22 (»Sve mu podloži pod noge, a njega postavi - nad svime - Glavom Crkvi «) i preuzima ekleziološku viziju deuteropaulina, a potom ju biblijsko-teološki (dakle sintetski) primjenjuje na ekleziološku složenu sliku te perikope Prve Petrove poslanice. Za tu perikopu prikladnije bi bilo prvotno primijeniti analitičku egzegetsku metodu kako bi se iščitala izvorna ekleziološka slika Prve Petrove poslanice, a potom ju uspoređivati s ostalim ekleziološki relevantnim biblijskim slikama. Norbert Brox se s obzirom na gore spomenuti motiv $\gg$ kamen ugaoni $\ll\left(\lambda i \theta_{0} v \dot{\alpha} \kappa \rho \circ \gamma \omega v i \alpha i \tilde{o v}\right)$ također slaže s mišljenjem Ericha Zengera smatrajući da nije riječ o završnom građevnom kamenu na vrhu zgrade, već o nosećem temeljnom i ugaonom kamenu na kojem stoji kuća, a ta je interpretacija dominirala u ranokršćanskim i srednjovjekovnim egzegetskim tumačenjima, u umjetnosti i u liturgiji. ${ }^{58}$ Ugaoni kamen u svakom slučaju simbolizira Krista, a kuća, odnosno dom ili građevina, simbolizira kršćansku zajednicu, ugrađivanje u tu građevinu kao »živo kamenje « simbolizira (povijesni) razvoj i ujedno život onoga što nazivamo Crkva, ekklesia, koja je u perikopi na poseban način tematizirana, premda se u Prvoj Petrovoj poslanici izričito kao teološki termin ne spominje. Današnja strukturiranost Crkve naravno da se ne može izjednačiti sa strukturiranošću onodobne kršćanske zajednice, ali već se u novozavjetnim tekstovima zapaža tijek toga prvotnoga eklezijalnoga razvoja koji i danas ima svoje osobitosti. Nedostatak izraza ekklesia u Prvoj Petrovoj poslanici proizlazi iz različitosti adresata kojima autor upućuje poslanicu, a to se, prema Gerhardu Hotzeu, uvelike razlikuje od Pavlovih poslanica. Gerhard Hotze smatra da

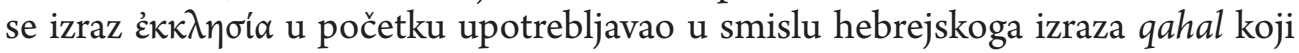
Septuaginta prevodi s ekklesia, koji je imao s jedne strane značenje eshatološkoga Božjega naroda, a s druge strane značenje konkretnoga skupa onih koji vjeruju u Krista. ${ }^{59}$ To posljednje značenje preuzima Pavao u svojim poslanicama i u pravilu

${ }^{57}$ Usp. A. M. STIBBS, Prva Petrova, 74.-75. Ekleziološke slike Crkve razlikuju se u pojedinim Pavlovim poslanicama, zbog čega ih, među ostalim razlozima, egzegete različito datiraju. Pavlovska slika Crkve predočena je Mističnim Tijelom Kristovim, koje čitavo predstavlja Krista, a svaki pojedini ud čine kršćani, što je slika tipična za tzv. protopauline (npr. Prva Korinćanima; usp. 1 Kor 12, 12-31). U deuteropaulinama (npr. poslanica Efežanima; usp. Ef 1, 22-23; 4, 15-16) Krist je glava Crkve, dakle glava Mističnoga Tijela Kristova, dok su kršćani udovi preostaloga dijela Mističnoga Tijela Kristova, čime se već nazire trag govora o hijerarhiziranosti Crkve, koja je još uočljivija zbog specifične terminologije u pastoralnim poslanicama ( 1 Tim, 2 Tim, Tit), za koje se stoga zaključuje da su najkasnije napisane.

${ }^{58}$ Usp. N. BROX, Der erste Petrusbrief, 1979., 100.

${ }^{59}$ Usp. G. HOTZE, Zur Ekklesiologie des Ersten Petrusbriefes, u: T. SÖDING (ur.), Hoffnung in Bedrängnis. Studien zum Ersten Petrusbrief, Stuttgart, 2009., 113.-114. 
se pritom koristi izrazom ekklesia jer se obraća nekoj mjesnoj konkretnoj zajednici, no za razliku od njega autor Prve Petrove poslanice obraća se više nego jednoj mjesnoj konkretnoj zajednici jer već u 1 Pt 1, 1 spominje pokrajine Pont, Galaciju, Kapadociju, Aziju i Bitiniju.

Raymond E. Brown ističe povijesnu važnost te perikope (osobito $1 \mathrm{Pt} 2,9$ ) za ekleziologiju. Redak 2, 9 kršćansku zajednicu krštenih prikazuje kao kraljevsko svećenstvo, a duhovna žrtva (r. 2, 5) koju prinose kršćani zapravo je njihov krepostan život. R. E. Brown spominje da je svećenička terminologija nastupila u 2. stoljeću u povezanosti s uporabom žrtvenoga jezika za euharistiju jer se u novozavjetnom vremenu ne spominje izraz »svećenik«, tj. hiereus kao kršćanski službenik, a opis naroda Božjega kao kraljevskoga svećenstva starozavjetna je terminologija prisutna u Izl 19, 6. Kako je već Izrael posjedovao posebno posvećeno svećenstvo s vlašću i dužnostima različitim od ostalih pripadnika izraelskoga naroda, Brown zaključuje da nema biblijskoga uporišta ni opravdanja tvrdnja da krsno svećeništvo isključuje postojanje posebno zaređenih svećenika. ${ }^{60}$ Eshatološki ton o sveopćem svećeništvu, prema Raymondu E. Brownu, vidljiv je ako se 1 Pt 2, 9 usporedi s Otk 1, 6 gdje se Isus Krist liturgijskim izrazima veliča jer $\gg$ učini nas kraljevstvom, svećenicima Bogu i Ocu svojemu « te u usporedbi s Otk 5, 10 gdje vidjelac o nebesnicima koji su za Boga otkupljeni po Kristu kaže: »učinio si ih Bogu našemu kraljevstvom i svećenicima i kraljevat će na zemlji. ${ }^{61}$ Mnogi egzegete koji su proučavali Prvu Petrovu poslanicu pozorno su odvagali svaki argument, detalj ili makar samo naznaku u tekstu kako bi se opredijelili za ranije ili kasnije datiranje ${ }^{62}$ same poslanice. Primjer ranije datacije poslanice ponudio je Wilfrid J. Harrington ocrtavajući tako petrovski, ${ }^{63}$ a ne pseudopetrovski, utjecaj na poslanicu i njezinu ekleziologiju. Harrington među ostalim argumentima spominje kako Petrovo autorstvo opravdava pojavljivanje mnogih aluzija na Isusove patnje kao zadovoljštinu (usp. $1 \mathrm{Pt}$ $1,18-19 ; 2,21-24 ; 3,18 ; 4,1)$, zatim često spominjanje i citiranje starozavjetnih izraza koji podsjećaju na Isusove riječi (usp.: 1 Pt 1, 16-17; 2, 4-5.8-10; 3, 14-15;

\footnotetext{
${ }^{60}$ Usp. R. E. BROWN, Uvod u Novi zavjet, 728.

${ }^{61}$ Usp. isto, 729.

${ }^{62}$ To ujedno odgovara i na pitanje autorstva i pseudonimnosti poslanice, ali još uvijek nema u tom pitanju zajedničkoga konsenzusa među bibličarima, već se odgovor na to pitanje traži u najplauzibilnijim argumentima. Ovdje se također postavlja pitanje datiranja ekleziološke slike prisutne u perikopi 1 Pt 2, 4-10, tj. u kojem je povijesnom vremenu opisana vizija Crkve, tj. kršćanske zajednice u perikopi.

${ }^{63}$ Harrington tvrdi da ta poslanica ne pokazuje nikakav znak žestokoga progona protiv Crkve u Rimu ili znak da je taj progon nedavno završio, te stoga datira poslanicu u 64. godinu uoči Neronova progonstva u Rimu, a autorstvo pripisuje Petru i pisaru Silvanu (tj. Sili) upućenom u grčki jezik i Septuagintu.
} 
4, 3.7.13.17-18; 5, 4.8-11) i paralele ${ }^{64} \mathrm{u}$ Petrovim govorima u Djelima apostolskim (usp.: 1 Pt 1, 10 i Dj 3, 18; 1 Pt 2, 4 i Dj 4, 11; 1 Pt 3, 22 i Dj 2, 33-34). S obzirom na izvore na temelju kojih je poslanica sastavljena, Harrington smatra da je neosporno postojanje određenoga utjecaja nekoga krsnoga liturgijskoga himna ili krsne kateheze, a stručnjaci se znatno slažu u tom pitanju. ${ }^{65}$ Perikopa $1 \mathrm{Pt} 2$, 4-10 sukladno toj podjeli i svojevrsnoj liturgijskoj hermeneutici predstavljala bi završni dio krsne kateheze poslije krštenja, odnosno mistagoške kateheze radi produbljivanja vjerskoga znanja i dublje upućivanje u Kristovo otajstvo kod krštenih vjernika. Za perikopu $1 \mathrm{Pt}$ 2, 4-10 također je značajna i socijalna dimenzija naglašena u izrazima: »rod izabrani, kraljevsko svećenstvo, sveti puk, narod stečeni (...) vi, nekoć Ne-narod, a sada Narod Božji; vi Ne-mili, a sada Mili.« Prema Norbertu Broxu ${ }^{66}$ spomenutim je izrazima opisano obraćenje i poziv kršćana iz poganstva, uz kontrastiranja $\gg n e-$ koć - sada « koja su tipična za tu poslanicu. Novo iskustvo socijalizacije relativno malih skupina kršćana proizlazi iz zajedničke vjere jer se prije nisu poznavali i nisu jedni drugima pripadali. Kršćani Ponta, Galacije, Kapadocije, Azije i Bitinije (1 Pt $1,1)$ sada predstavljaju etničku, društvenu i nacionalnu mješavinu, ali se međusobno ipak nazivaju jedan $\gg$ narod Božji $\ll(\lambda$ aò $\theta \varepsilon o \tilde{v})$.

Thomas Söding naglašava ekumensku važnost perikope 1 Pt 2, 4-10 kojoj se Martin Luther uvijek iznova vraćao i citirao ju kako bi ukazao na onodobne negativne vidove katoličkoga odnosa između svećenstva i vjerničkoga puka, kao i načelno ista prava i iste dužnosti svih kršćana. ${ }^{67}$ Söding ističe u perikopi dva starozavjetna biblijska motiva: metaforu kamenja i metaforu kuće koji su u službi svojevrsne teologije izabranja. Ta se teologija izabranja ${ }^{68}$, kojom je obilježena perikopa, primarno usmjeruje kristološki (1 Pt 2, 4.6), a potom se primjenjuje ekleziološki (1 Pt 2, 9). Izabranje pritom smjera ne samo na Židove već i na pogane ( $1 \mathrm{Pt} 1,14.18 ; 2,10.25$; $3,6 ; 4,3)$, na muževe i žene ( $1 \mathrm{Pt} 3,1.7)$, mlade i stare (1 Pt 5, 5), na siromašne i

${ }^{64}$ Usp. W. J. HARRINGTON, Uvod u Novi zavjet, 380.-381.

${ }^{65}$ U skladu sa svojevrsnom liturgijskom hermeneutikom Prva Petrova poslanica dijeli se na: a.) Uvodna molitva krsnoga himna: 1 Pt 1, 3-12; b.) Krsna kateheza prije krštenja: 1 Pt 1, 13-21; c.) Krsna kateheza poslije krštenja: 1 Pt 1, 22-2, 10; d.) Krsno vjerovanje: 1 Pt 3, 18 - 4, 6; e.) Parenetski odsjek o kršćanskom pozivu: 1 Pt 2, 11 - 3, 7; 5, 5-9; f.) Niz preporuka za razdoblje progona: 1 Pt 1, 13-17; 4, 12 - 5, 4; 5, 10-11. Usp. W. J. HARRINGTON, Uvod u Novi zavjet, 379.

${ }^{66}$ Usp. N. BROX, Der erste Petrusbrief, 1979., 107.

${ }^{67}$ Thomas Söding prikazao je kratku analizu perikope 1 Pt 2, 4-10 i njezin kontekst u Prvoj Petrovoj poslanici; usp. T. SÖDING, Višse od Knjige. Razumjeti Bibliju, Zagreb, 2001., 283.-291.

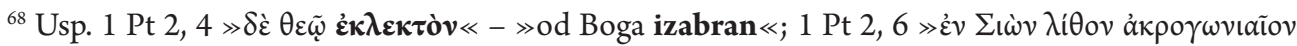

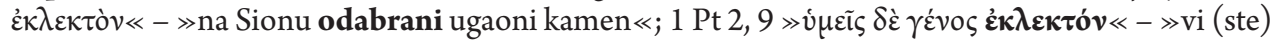
rod izabrani $\ll$. Prema T. Södingu izabranje kršćana u Prvoj Petrovoj poslanici povezano je s krštenjem. 
bogate (1 Pt 3, 3), kao i na robovlasnike i robove (1 Pt 2, 18 s), a kršćani su pritom kao pripadnici naroda Božjega postavljeni nasuprot profanom svijetu. Način na koji Thomas Söding dijeli »prijašnje « $i$ »sadašnje « stanje novoga naroda Božjega zapravo počinje s tom perikopom i proteže se na cijelu poslanicu, a može se prikazati na sljedeći način: A.) nekoć $\gg$ Ne-narod $\ll(\mathbf{1} \mathbf{P t ~ 2 , ~ 1 0 )}$; hrpa neznalica $(1,14)$; zalutali ljudi $(2,25)$; tjerani vlastitim strastima $(1,14 ; 4,2 s)$; predani nestalnom životu $(1,14)$; predani pokvarenom životu $(4,3)$; predani besmislenom životu $(1,18)$; B.) a sada Narod Božji (1 Pt 2, 10); imaju utemeljenu nadu u vječni život (1,3s; 3, 15s); došli su k vjeri, »vjeri u Boga « $(1,21)$; osvjedočeni su u istinitost vjere $(1,22 a)$; naučili su i iskusili bratsku ljubav (1,22b); oslobođeni od ništavnosti dosadašnjega života (4, 1-6); pripadaju Isusu Kristu (2, 4s; 2, 21-25; 3, 18); Krist ih okuplja i pruža im zavičaj $(2,25)$. Taj prikaz, ${ }^{69}$ premda ukazuje na svojevrsnu dihotomiju između prijašnjega i novoga stanja kršćana, podsjeća na kontrast koji se pojavljuje i u perikopi $1 \mathrm{Pt}$ 2, 4-10 vezano uz one koji u Krista vjeruju i one koji ne vjeruju u Krista odbacujući ga. Thomas Söding zaključuje da Prva Petrova poslanica u drugom poglavlju ne tematizira sam odnos između »općeg «i »posebnog « svećenstva niti govori o specifičnim kompetencijama ili pravima članova Crkve, već govori o značenju i pozivu Crkve (Eklezije). Kršćani su pritom, kao svećenici, pozvani i osposobljeni bogoslužjem i životom omogućiti da Duh gradi »duhovni dom《ispunjen Božjom nazočnošću i dopustiti Bogu da ih po Isusu Kristu uzme u službu naviještanja. ${ }^{70} \mathrm{U}$ ovom pregledu različitih egzegetskih razmatranja nad perikopom $1 \mathrm{Pt}$ 2, 4-10 zaključno bi se moglo iznijeti mišljenje Christopha Gregora Müllera koji, referirajući se na druge autore, smatra da se zadaća kraljevskoga svećenstva može opisati kao poslušnost Bogu, svetost i posredujući Boga drugim narodima ispuniti svoju svećeničku ulogu. To znači da kršćani kao kraljevsko svećenstvo imaju poziv Božja djela u Isusu Kristu objaviti ljudima i tako prinositi duhovne žrtve, Bogu ugodne. ${ }^{71}$

\section{Zaključak}

Perikopa o kamenu ugaonom i narodu Božjem, kraljevskom svećenstvu, u Prvoj Petrovoj poslanici (1 Pt 2, 4-10) nalazi se između perikope u kojoj se navode savjeti koji se tiču zajedničkoga života ( $1 \mathrm{Pt} 1,22-2,3)$ i perikope u kojoj se govori o ispravnom ponašanju kršćana među poganima, tj. nevjernicima (1 Pt 2, 11-12). Na nastanak Prve Petrove poslanice moguće da je utjecao neki oblik krsnoga liturgijskoga himna ili krsne kateheze te bi u tom smislu perikopa $1 \mathrm{Pt}$ 2, 4-10 predstavljala

\footnotetext{
${ }^{69}$ Usp. T. SÖDING, Više od Knjige, 285.-286.

${ }^{70}$ Usp. isto, 291.

${ }^{71}$ Usp. C. G. MÜLLER, Auserwählte als Fremde, u: M. EBNER, G. HÄFNER, K. HUBER (ur.), Der erste Petrusbrief. Frühchristliche Identität im Wandel, Freiburg im Breisgau-Basel-Wien, 2015., 41.
} 
završni dio krsne kateheze nakon krštenja, tj. mistagoške kateheze. Hermeneutika Staroga zavjeta u tom novozavjetnom složenom tekstu nužna je za produbljenu egzegetsku analizu perikope jer na taj način postaju vidljivi starozavjetni tekstovi koji predstavljaju paralelne izraze ili svojevrsnu aluziju na određeni redak iz perikope. Struktura same perikope može se promatrati sadržajno-logički, dijeleći perikopu na tri dijela: 1.) $1 \mathrm{Pt}$ 2, 4-5 gdje je središnji motiv sveto svećenstvo, tj. kršćani, 2.) $1 \mathrm{Pt}$ 2, 6-8 gdje je središnji motiv kamen ugaoni, tj. Isus Krist u kristološkoj interpretaciji i 3.) 1 Pt 2, 9-10 gdje je središnji motiv narod Božji, tj. kršćani. Na taj način zapaža se uokvirenost središnjega motiva, tj. Isusa Krista, ugaonoga kamena s motivom kraljevskoga svećenstva, naroda Božjega koji predstavlja kršćanske vjernike. Drugi način pronalaženja strukture same perikope više je vezan uz povijest nastanka perikope. Zamjećuje se određena strukturalna sličnost perikope sa židovskim midrašem, osobito s pešarimom kakvi su pronađeni u Qumranu, zbog čega neki egzegete smatraju da se perikopa, u skladu s onodobnom židovskom egzegetskom praksom, sastoji od naizmjeničnih citiranja i tumačenja starozavjetnih tekstova što zahvaća središnji dio perikope (1 Pt 2, 6-8). Postoje također mišljenja da perikopi nije prethodio tekstualni predložak niti skup svjedočanstava jer povezani i posljedični slijed misli unutar perikope, kao i njezin položaj u poslanici, odaju originalnost autora koji je na svoj način utkao gore navedene starozavjetne citate (ili makar samo aluzije). Izborom motiva koji se ponavljaju u Starom zavjetu i perikopi i birajući semantički istaknutije motive u perikopi uz naknadni izbor (iz literature) egzegetima zanimljivih motiva u ovom radu izabrani su motivi egzegetski analizirani i kontekstualizirani tehnikom hermeneutike Staroga zavjeta u Novom zavjetu. Posljedično tome može se zaključiti u kojim teološki relevantnim pravcima smjera poruka te teološki složene perikope. Daljnja biblijsko-teološka i egzegetska analiza perikope, oslonjena uvelike na literaturu, pokazuje ekleziološku važnost perikope $1 \mathrm{Pt} 2$, 4-10, koja u tom pogledu proširuje kratku ekleziološku skicu iz $1 \mathrm{Pt} 1,1$ pružajući, kao jedna od najgušćih konstelacija eklezioloških slika u Novom zavjetu, mogućnost da se oštrije i dublje razabire temelj, postojanje, bit i svrha Crkve. Iz egzegetske perspektive u toj perikopi može se nazrijeti, makar samo implicitno, dogmatsku kristološku istinu o božanskom identitetu Isusa Krista, tj. njegovo božanstvo i čovještvo. Motiv »dragocjenog kamena ugaonog « kristološkim se tumačenjem identificira s osobom Isusa Krista. U pogledu ekleziološke slike koju ta perikopa nudi ponovno se treba vratiti na tri ključna motiva iz gore navedene osnovne, sadržajno-logičke podjele perikope na tri dijela, a to su: kraljevsko svećenstvo (tj. kršćani, Kristovi vjernici), kamen ugaoni (tj. Isus Krist) i narod Božji (tj. kršćani, Kristovi vjernici). Motiv kraljevskoga svećenstva iz $1 \mathrm{Pt} 2$, 9 povezuje (biblijsko-teološki gledano) cijelu perikopu s knjigom Otkrivenja (Otk 1, 6; 5, 10) dajući eshatološki ton sveopćem svećenstvu. Sveopće je svećenstvo teološki termin koji je u dogmatskoj teologiji odigrao iznimno velik utjecaj, osobito na području dogmatske sakra- 
mentologije (sakrament svetoga reda, a posredno sakrament euharistije i ostali sakramenti), dogmatske ekleziologije i posljedično tome na područje soteriologije. U razvoju događaja reformacije 16. stoljeća jednu od presudnih uloga odigralo je pogrešno tumačenje retka te perikope $1 \mathrm{Pt} 2,9$ kojim je Martin Luther pokušao osporiti potrebu za ministerijalnim svećenstvom, tumačeći da po krštenju svi kršćani postaju na jednak način svećenici. Drugi vatikanski sabor uočio je važnost perikope 1 Pt 2, 4-10 citirajući ju u LG 6 (kontekst pralikova Crkve), LG 9 (kontekst Crkve kao novoga naroda Božjega), LG 10 (kontekst Crkve kao svećeničkoga i proročkoga naroda, gdje se tematizira i opće svećenstvo krštenih vjernika), LG 34 (gdje se spominje svećenička služba laika koja u konačnici postaje duhovno bogoslužje na slavu Božju i na spas ljudi), SC 14, AA 3, PO 2, AG 15. Iz svega navedenoga može se zaključiti da je perikopa 1 Pt 2, 4-10 prepoznata kao iznimno utjecajan biblijski tekst, osobito u pogledu dogmatske i ekumenske teologije. Moguće je također navesti elemente teologije izabranja kojom je, prema nekim egzegetima, obilježena ta perikopa i cijela poslanica, a kristološko-ekleziološki usmjerena je prema Židovima i poganima, muževima i ženama, mladima i starima, siromašnima i bogatima, robovlasnicima i robovima. To izabranje u toj je perikopi kontrastirano svojevrsnom dihotomijom između prijašnjega i novoga stanja kršćana te između onih koji u Krista vjeruju i onih koji ne vjeruju u Krista odbacujući ga. Socijalna dimenzija perikope naglašena u izrazima $\gg$ rod izabrani, kraljevsko svećenstvo, sveti puk, narod stečeni (... ) vi, nekoć Ne-narod, a sada Narod Božji; vi Ne-mili, a sada Mili« izražena je novim iskustvom socijalizacije relativno malih skupina kršćana (Ponta, Galacije, Kapadocije, Azije i Bitinije) kojima sada postaje zajednička vjera u Krista, uzrok da se kao etnička, društvena i nacionalna mješavina međusobno ipak nazivaju jedan $\gg$ narod Božji $(\lambda$ aòs $\theta \varepsilon o \tilde{v})$. Zaključno se može reći, citirajući samu perikopu, da kršćani kao kraljevsko svećenstvo imaju poziv Božja djela u Isusu Kristu objaviti ljudima i tako prinositi duhovne žrtve, Bogu ugodne. 


\title{
THE PERICOPE ON THE CORNERSTONE AND THE PEOPLE OF GOD - THE ROYAL PRIESTHOOD IN THE FIRST EPISTLE OF PETER (1 PETER 2:4-10)
}

\author{
Mario CIFRAK - Vedran PAVLIĆ*
}

Summary: The First Epistle of Peter in the pericope 1 Peter 2:4-10, in speaking about Christ as the cornerstone and the People of God who are called here the royal priesthood, reveals a specific Petrine ecclesiological image. The ecclesiologically relevant results in this paper are achieved through exegetical analysis using the techniques of hermeneutics of the Old Testament in the New Testament, through exegetical analysis with the contextualization of the more important motives in the pericope and through further exegetical and biblical-theological analysis based on the literature of Biblical exegetes who have commented on this pericope. The important motives that are found in this pericope do not have only their New Testament context with the Christological or ecclesiological meaning and implications, but also their Old Testament background, context and semantics. The motive of royal priesthood, which in this pericope points to the entire People of God, to the Christian believers, so the whole Ecclesia, has been interpreted incorrectly in the circumstances of the 16th century Reformation (especially 1 Peter 2:9), which led to theological misrepresentations on the dogmatic field. The Second Vatican Council cited this pericope in its documents (SC 14, AA 3, PO 2, AG 15, and particularly in: LG 6; $9 ; 10 ; 34)$ interpreting the ecclesiology with expressions from the pericope among which the images of the Church as the People of God and the royal priesthood, i.e. the universal priesthood of the baptized, are especially significant.

Keywords: First Epistle of Peter, cornerstone, the People of God, the royal priesthood, the hermeneutics of the Old Testament in the New Testament, the ministerial and universal-baptismal priesthood.

\footnotetext{
* Assoc. Prof. Mario Cifrak, Ph. D., Catholic Faculty of Theology, University of Zagreb, Vlaška 38, 10000 Zagreb, Croatia, mario.cifrak@ofm.hr

Vedran Pavlić, mag. theol., Karmel - Remete, Ivana Česmičkoga 1, 10000 Zagreb, Croatia, vedranpavlic.ocd@gmail.com
} 